\title{
8
}

\section{The Birds and the Bees: The Origins of Sections in Queensland}

\author{
Patrick McConvell
}

\section{Introduction}

The 'section' type of social categorisation is only found in Indigenous Australia, with one exception in South America that will be discussed briefly in this chapter. The sections are a system of four named divisions in which members of each section have a particular kinship relation to each other section. Corresponding pairs of sections have a relationship of marriage alliance with each other. In the older literature, sections are called 'classes', 'sub-classes' or 'marriage classes'. The section 'How Sections Work' provides a sketch of the functioning of this system; however, the main aim of the chapter is to attempt to ascertain the origins of the section system.

This task begins in the section 'Subsections Arose from Sections' in which the history of the subsection system is analysed. Subsections are only located in the central north of Australia, spread out from an area near the town of Katherine in the Northern Territory. Since subsection systems arose more recently from section systems, their history is more transparent and provides a starting point from which to track the origin of sections. The section 'The Distribution of Section Systems in Australia' describes 
the geographical distribution of sections that are found surrounding the area of subsections on all sides, in small pockets to the north and south and in very large areas to the east and west. The reason for this pattern is that during their distribution, subsections either diffused to replace previously existing section systems or other forms of social categories. A general idea of the number and location of different section terminologies is also provided.

The section 'Section Systems in Queensland' moves on to our main focus: the section systems in Queensland. There is reason to believe that Queensland may be the area of origin of section systems in Australia more generally, which forms part of the hypothesis being explored. A number of hypotheses have been proposed in regard to how section systems could have originated (including my own hypothesis) and these hypotheses are briefly mentioned. The subsections 'Hypotheses That Sections Arose from the Combination of Different Types of Moiety', 'Hypothesis That Sections Arose from the Combination of the Same Kind of Moiety or Phratry' and 'Sections in the Mapoon Area, North-Western Cape York' propose a new hypothesis that sections arose from the merging of two groups with moieties or phratries of the same lineality (patrilineal in the cases considered here) and the institution of a circulating connubium between them. Once regularised, this type of marriage exchange yielded a section system. Examples of the outcome of such processes are provided for northern Queensland.

In the section 'The Queensland General Section System', the example of a very widespread section system - the 'Queensland General' system contiguous to the other coastal systems discussed in the section 'Section Systems in Queensland'-illustrates how linguistic evidence of form of terms can be crucial in tracing the origin and diffusion of such systems, especially in a case such as this in which the processes are relatively more recent. Of course, it is not possible to trace the development of all section systems in Queensland within the confines of this chapter; however, by addressing one section system in detail—one that was still spreading in the twentieth century-we furnish a preview of how a more complete history can be provided by linking back to the earliest origins of sections.

The section 'Broader Perspectives' looks briefly at these findings from the broader perspectives of: 1) other features in Queensland-language phylogenies and moiety systems; 2) estimates of the age of the Queensland section systems and possible correlates in the archaeological record; 
3) preliminary work that David Fleck and I conducted on the section systems among Panoan-speaking groups in South America, and its relevance to the Queensland case; and (4) how these findings may or may not fit in with speculative accounts of 'early human kinship' featuring section-like structures, such as by Nicholas Allen in his tetradic theory. The section 'Conclusions' offers a summary, conclusions and recommendations for further research.

\section{How Sections Work}

In a group that has sections, everyone has a section by virtue of being born to parents who have different sections from the child. One's father has a different section from oneself, and so does one's mother. The fourth section is that of one's spouse or potential spouse, and includes one's first cross-cousins. Not only are these basic kin types but all relations also fit into this scheme on the basis of familiar extension rules. For instance, 'father's father' and 'mother's mother' belong to the same section as ego. This illustrates that sections cycle back in every alternate generation-a key property of the system.

If the marriage of the parents is of the first preferred, or 'straight' type, then there will be no question about the assignment of a section term to the children. However, if the marriage is not of this type, then assignment based on the father will be different from that based on the mother. Various principles and strategies are deployed in different groups to settle this question.

The function of sections in determining correct marriage partners has already been mentioned. However, the functions are much broader than this: with a section name, one can be fitted into families of apparent strangers and call them by kinship terms without necessarily knowing their genealogical connections to oneself, or indeed even having any. Thus, many non-Aboriginal and Aboriginal people from areas without sections or subsections can be assigned 'skin' names by Aboriginal people and be incorporated in this way. Thus, the section and subsection systems contribute to broadening the scope of 'universal kinship classification' (Barnard 1978), whereby everyone can call everyone else by a kinship term. 
The scope of the section or subsection systems does not terminate when different terms are used. Users of the system are usually entirely familiar with the 'pragmatic equivalence' rules between different terminologies over a wide area (McConvell \& McConvell 2015). Therefore, the ambit of the section system is much wider than a single 'society' or language group and operates in a highly extended intercommunal space.

\section{Subsections Arose from Sections}

Subsections, or 'skins' as they are colloquially known (for the history of this term, see Chapter 9), are still commonly used across a wide area of the Northern Territory and parts of Western Australia and Queensland. In contrast to sections with four divisions, subsections have eight divisions, based on similar principles to those of sections but with each section divided into two subsections. For instance, while 'father's father' and 'mother's mother' fall into the same section in a section system, they fall into two separate subsections in a subsection system.

The subsection system of the Warlpiri terminology in the Tanami Desert of the Northern Territory is illustrated in Table 26.

Table 26: Warlpiri subsections.

\begin{tabular}{|l|l|l|l|l|}
\hline Code & Terms & & Code & \\
\hline $\begin{array}{l}\text { A1m } \\
\text { A1f }\end{array}$ & $\begin{array}{l}\text { Japanangka } \\
\text { Napanangka }\end{array}$ & Marry & $\begin{array}{l}\text { B1m } \\
\text { B1f }\end{array}$ & $\begin{array}{l}\text { Jupurrurla } \\
\text { Napurrurla }\end{array}$ \\
\hline $\begin{array}{l}\text { A2m } \\
\text { A2f }\end{array}$ & $\begin{array}{l}\text { Jungarrayi } \\
\text { Nungarrayi }\end{array}$ & Marry & $\begin{array}{l}\text { B2m } \\
\text { B2f }\end{array}$ & $\begin{array}{l}\text { Jangala } \\
\text { Nangala }\end{array}$ \\
\hline & & & & \\
\hline $\begin{array}{l}\text { C1m } \\
\text { C1f }\end{array}$ & $\begin{array}{l}\text { Jakamarra } \\
\text { Nakamarra }\end{array}$ & Marry & $\begin{array}{l}\text { D1m } \\
\text { D1f }\end{array}$ & $\begin{array}{l}\text { Japaljarri } \\
\text { Napaljarri }\end{array}$ \\
\hline $\begin{array}{l}\text { C2m } \\
\text { C2f }\end{array}$ & $\begin{array}{l}\text { Jampijinpa } \\
\text { Nampijinpa }\end{array}$ & Marry & D2m & $\begin{array}{l}\text { Japangardi } \\
\text { Napangardi }\end{array}$ \\
\hline
\end{tabular}

Source: Author's work.

Further insight into the process that created subsections came from studying the linguistic forms in subsections in comparison to sections (McConvell 1985, 1997). The following was found:

1. The roots in four of (half of) the subsections on the western side of their distribution came from the western section terms-for instance, they were found in the Pilbara. 
2. The roots in the other four of (half of) the subsections on the western side of their distribution came from the northern section terms, in an area south of Darwin.

This immediately suggests that the new subsection system arose from a merger of two previous section systems that came from different directions. Further, the two component sets, from the west and north, have a regular relationship to each other. Table 27 shows that the Kariera system, as represented by Radcliffe-Brown (1931), uses the same A-D system as for subsections. Table 28 shows the Warray system of the north, as recorded by Spencer (1914, pp. 53-4). Spelling has been adjusted to modern standards.

Bearing in mind that subsection terms have acquired masculine and feminine prefixes $j a$ - and $n a$ - respectively in their early history (see McConvell 1985), A and C in Kariera are clearly related to subsections $\mathrm{A} 1$ and $\mathrm{C} 1$ respectively in Warlpiri (and many other systems), and C and $\mathrm{D}$ in Warray are clearly related to C2 and D2 in the Warlpiri (and other) subsection systems (note: Warray terms have the normal masculine and feminine prefixes $a$ - and $a l$ - respectively in that language). Terms in other variants of western sections are related to variants of subsection systems; however, brevity does not permit an account of this, nor of McConvell's $(1985,1997)$ hypothesis about the marriage system that led to the origin of the subsection system.

Table 27: Kariera sections.

\begin{tabular}{|l|l|l|l|l|}
\hline Code & Terms & & Code & \\
\hline A & Panaka & Marry & B & Purung \\
\hline & Mother/child of & & & Mother/child of \\
\hline C & Karimarra & Marry & D & Milangka \\
\hline
\end{tabular}

Source: Radcliffe-Brown (1913, 1931).

Table 28: Warray sections.

\begin{tabular}{|l|l|l|l|l|}
\hline Code & Terms & Marry & $\begin{array}{l}\text { Bm } \\
\text { Bf }\end{array}$ & $\begin{array}{l}\text { apularan } \\
\text { alpularan }\end{array}$ \\
\hline $\begin{array}{l}\text { Am } \\
\text { Af }\end{array}$ & $\begin{array}{l}\text { Awinmij } \\
\text { Alinmij }\end{array}$ & Mother/child of & & Mother/child of \\
\hline $\begin{array}{l}\text { Cm } \\
\text { Cf }\end{array}$ & $\begin{array}{l}\text { Ajampij } \\
\text { Aljampij }\end{array}$ & Marry & $\begin{array}{l}\text { Dm } \\
\text { Df }\end{array}$ & $\begin{array}{l}\text { apangarti } \\
\text { alpangarti }\end{array}$ \\
\hline
\end{tabular}

Source: Harvey (1986) and Spencer (1914). 
The idea that subsections arose from sections is not new. Davidson (1928, pp. 93-4) proposed that:

The eight-class system represents a development out of the four-class organization.

The linguistic evidence mentioned above is new and conclusive. Those who proposed scenarios for subsection origins have invariably suggested a split in sections internally (e.g. von Brandenstein 1982); however, the linguistic evidence points to the correctness of the merger of two systems through a particular type of marriage exchange.

Davidson (1928, pp. 93-4) went on to say:

The four classes [sections] have resulted from the foundation of the dual grouping [moieties].

This hypothesis is explored in the next sections.

\section{The Distribution of Section Systems in Australia}

Systems of four sections are found across a large part of Australia. We begin in north Queensland - the area of most divergence between the terms in the systems - and work south and west to where the blocks of related terminology are generally larger. The numbered categories indicate terminologies in which the terms are generally linguistically related to each other within the category; the terms are generally not linguistically related between categories.

1. South-western Cape York Peninsula (SWCYP)

2. Central Cape York Peninsula (CCYP)

3. South-eastern Cape York Peninsula (SECYP)

4. Western Queensland (Kalkatungu and Mayi languages) (WQ)

5. Western Kukatj (WK) ${ }^{1}$

6. North-east Queensland (NEQ) ${ }^{2}$

1 McConvell (1985, pp. 14, 23) suggested that these section terms were drawn from the neighbouring subsection terminology.

2 This set of terms overlaps that of QG in some cases. See the section 'Section Systems in Queensland'. 
7. Queensland General (QG)

8. East central Queensland (ECQ)

9. South-east Queensland (SEQ)

10. North-east New South Wales (NENSW)

11. New South Wales General (NSWG)

12. Western (W) (a: WA from Pilbara west, b: eastern branch-E. Arandic; Yarruwinga has $\mathrm{C}$ and $\mathrm{D}$ terms related to E. Arandic, but $\mathrm{A}$ and $\mathrm{B}$ are distinct-possibly related to western Queensland terms) 13. North-central (NC) (Warray and Uwinymirr, south of Darwin).

The areas covered by these section sets are shown on Figure 24 and some of the Queensland terminologies will be discussed later in this chapter.

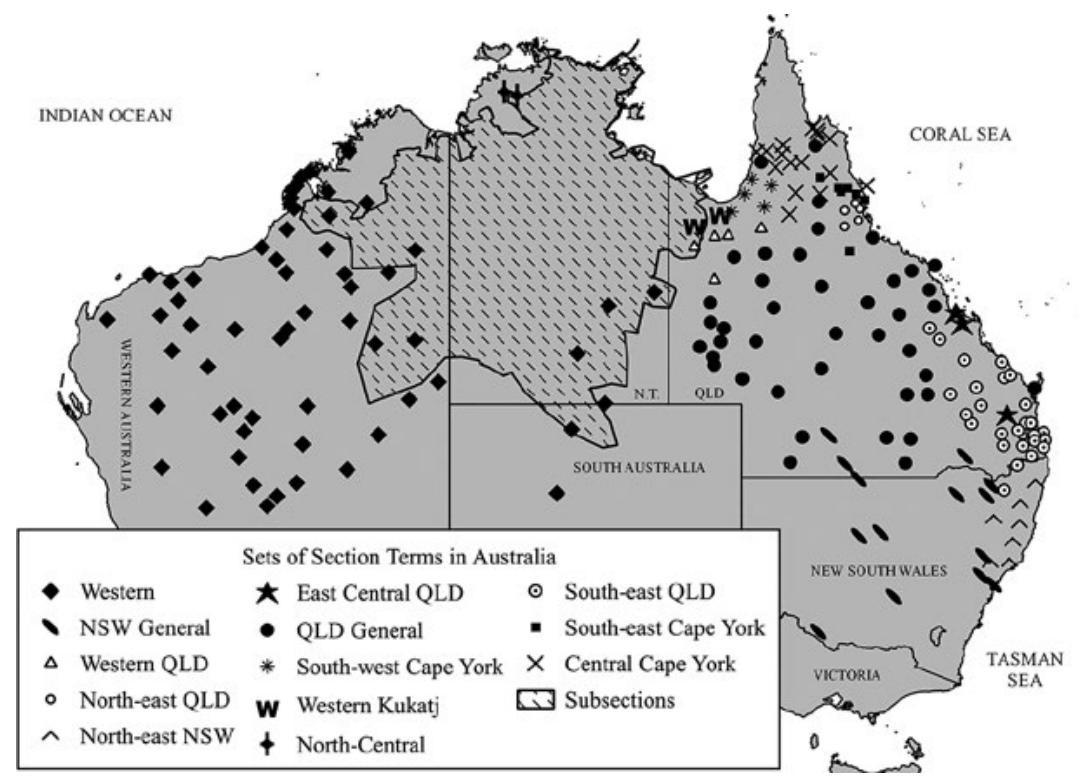

Figure 24: Sets of section terms in Australia.

Source: Prepared by William McConvell from the AustKin database.

I have avoided the use of the term 'cognate' for related terms, as this would imply that the terms descend from a common protolanguage by inheritance. It is fairly clear that many-probably most-section and subsection terms have spread by diffusion as loan words rather than by inheritance. There is a correlation between some of the sets of terms and Pama-Nyungan subgroups, such as between QG and Maric, and south-east Queensland and Waka-Kabic. However, there are problems in 
assuming that it is inheritance that is the motor of spread rather than diffusion in these cases. First, while the subgroups named have had some historical linguistic work done on them, the work has not been conclusively validated. Second, even if there is isomorphism between the terms in a set and the subgroups, it could still be that the terms are diffused; thus, further investigation of the cognate/loan word status of the terms is needed. This will be further discussed in relation to the QG section system and Maric in particular.

The asymmetry between the east and west in regard to the quantity of divergent section systems has been noted before. Davidson (1928, p. 120) wrote:

For the entire area of central and western Australia, there are but three different sets of class [section] names ... these occupy a region approximately twice the size of the other twelve. Certainly we may conclude that in the western region the diffusion was comparatively rapid. ${ }^{3}$

Davidson's Map 9 (1928, p. 120; see Figure 7 in Chapter 3) also shows a comparatively higher concentration of different section sets to the east of north Queensland. According to Davidson's geographical distribution theory, this implies that sections were older and diffused more slowly in this area. I now focus specifically on Queensland to ascertain if there is any other evidence that points to the origin and early development of sections in this region.

\section{Section Systems in Queensland}

\section{Tracing Connections between Diverse Systems}

In the list of sections sets, 1 to 9 are located in Queensland, with 10 and 11 slightly overlapping into Queensland from New South Wales to the south. While most of these will be mentioned in passing, most attention will be paid to sets 6 to 9 in this chapter.

Some of these sets do have some admixture of terms from neighbouring systems, but they are generally self-contained and do not exhibit any clear relationship with other sets in regard to the form of terms. This is

3 Davidson's mapping was based on earlier data but the overall picture is substantially correct. The east-west asymmetry is actually even more pronounced, since the central and western terminologies are related rather than separate. 
in contrast to subsections in which there are many similarities in forms between different systems. Such a divergence among the section systems suggests that the sections are substantially older than subsections-which we already know, since subsections arose from sections. The diversity of the terminology is greater in the north of Queensland compared with the centre and south, which perhaps suggests a northern origin. However, this is not a foregone conclusion; for instance, McConnel (1939) suggested that at least one of the Cape York Peninsula systems diffused from further south.

The forms of the section terms are generally completely different in the different sets, making the discovery of common original forms an impossible task. ${ }^{4}$ However, what is more promising is the idea that there may be a common semantic element in the etymologies of some terms, which can tell us about their origin and diffusion. Non-section meanings are sometimes, but not always (or at least not reliably), reported for sections, and moiety names are nearly always associated with a totemic animal (or more rarely, other natural phenomena). The possibility of section terms being derived from moiety names will be examined next. Evidence shows that some moiety names have the same or similar etymologies-for instance, from bird and bee species, even though they are different in form. It could then be posited that similar meanings of these social category terms diffused between areas, even though the forms of the names of the species are different.

This research into section term origin and diffusion is at the early stages, but there is enough to draw on to begin building hypotheses. I pursue the idea that sections emerged from the interaction of two moiety systems of the same kind in a specific kind of marriage exchange; however, we first need to examine a more popular idea regarding their origin-that sections arose from the interaction of moieties of different kinds.

\section{Hypotheses That Sections Arose from the Combination of Different Types of Moiety}

The most common hypothesis about the origin of sections is probably that they arose from the combination of different types of moiety. Three possibilities exist that could all structurally yield a section system:

4 There are close similarities between one or two terms in the western Queensland set and the subsections and Arandic sections to the west that suggest a common element, particularly in regard to the term kangila. 
- patrimoieties and matrimoieties

- patrimoieties and generational moieties

- matrimoieties and generational moieties.

In Queensland, overtly named generational moieties are not known; however, there is an alternative generation equivalence in the kinship systems. The most promising as a combination that could structurally yield a section system is that of the patrimoieties and matrimoieties, as both are known in Queensland, with some areas of close contact or overlap. These are shown in Figure 25.

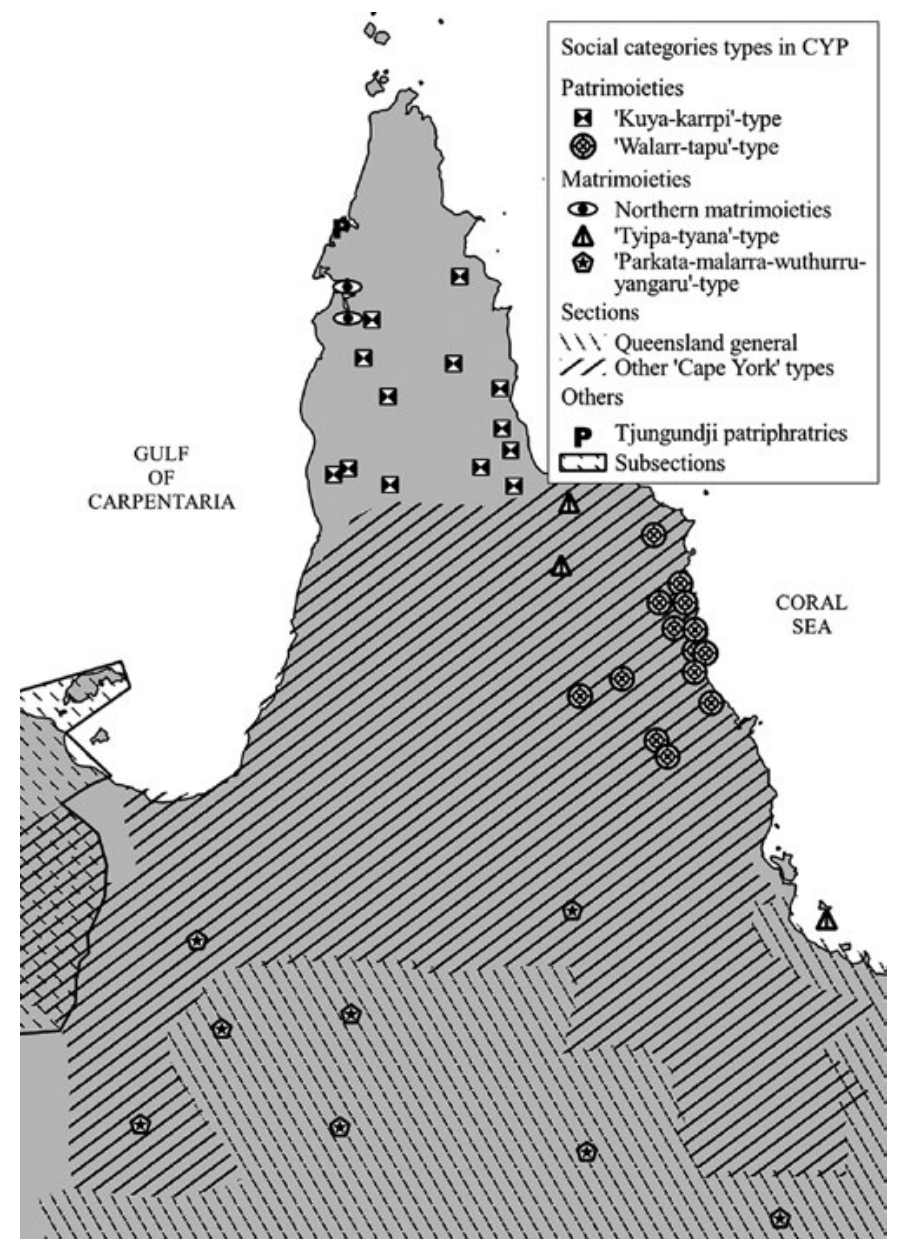

Figure 25: Social category types in Cape York Peninsula.

Source: Prepared by William McConvell from the AustKin database, and information collected from various sources by Patrick McConvell. 
These areas would be good candidates for the origin of sections if the hypothesis of section origin from a combination of patrimoieties and matrimoieties was valid. However, there is no clear evidence of the combination of patrimoiety (or patriphratry) terms with matrimoiety terms to form a section system:

1. In the north of Cape York, there are reported areas of matrimoieties in close proximity to named patriphratries (McConnel 1939; Sharp 1939, p. 265). However, there are no known section systems this far north - the most northerly extent of sections is far south of this area.

2. In the north-eastern Cape York, there is an area of patrimoieties with the names of two contrasting bee species, kuya and karrpi, with a small area of matrimoieties, tyipa and tyana, just to the south. These areas are adjacent to a region of sections to the west across the Cape York Peninsula; however, there is no telltale evidence of the combination of patrimoiety and matrimoiety terms. One of the closest section systems is that of the south-east Cape York Peninsula (Mbabaram, Dixon 1991; and Djangun, Sharp 1939), which is shown in Table 29. In this instance, one possible term with external relations is $\mathrm{D}$ Karpandji, which is similar to the regional bee patrimoiety term karrpi (-ntyi appears to be a suffix in all the terms except B Worpu). This connection is considered later in exploring section origin as the meeting up of two patrimoiety systems. Worpu (wurrpu) is also a bee term in the region and is probably a later importation in northwestern groups, replacing the term TyilantyilKilantyi, cited by Sharp (1939) and Mathews (1899), for more south-eastern groups. ${ }^{5}$ D Kupamay be related to the D section (Kuparu/Kupuru) of the QG system (see section 'The Queensland General Section System').

5 For instance, 'hornet, bumblebee' as in Kuku-Yalanji (Herschberger \& Herschberger 1986); a related term wurripa 'native bee (sugar bag bee) (bigger than watyan, with a beard)' (Tsunoda 2003, p. 115). Watyan (Tsunoda 2003, p. 102) is 'smaller than wurripa and kurtya'. In the closely related language Gugu-Badhun (Sutton 1973, p. 186), there are also three terms for native bee species: wurripa, wathan and kurtya. Kurtya is a term related to kutya and kuya, with a wide distribution in Queensland (see the subsection 'Hypothesis That Sections Arose from the Combination of the Same Kind of Moiety or Phratry'). This suggests that there may be three relevant species in the region; however, there may be factors entering into the emic classification that are not aligned with scientific species such as habitat and nest-type. The fact that there appears to be an alternation between initial $k$-and $t y$-in the older form for this section kilantyiltyilantyi reflects a wider sound correspondence in the rainforest and some Maric languages (see the section 'The Queensland General Section System'). If the earlier form is kila+, it may be related to the section/subsection root kangilalkela further west. 
3. The same matrimoieties mentioned in (2) are also in contact with another region of patrimoieties to the south named after the two bees, but with different names-walar and dabu. Again, there is no apparent connection between the matrimoiety terms and the adjacent section terms.

4. South of Cape York Peninsula, on the east coast, there is a further occurrence of the two bees patrimoieties with terms undoubtedly related to those in (2)-kuya and karilba. There is another widespread matrimoiety system to the west with the terms wuthurru and yangurru (with no known species translations thus far ${ }^{6}$ ). There is a gap between the patrimoiety area and the matrimoieties in this case, so it is not surprising that there is no interaction or combination of these systems. However, one of these matrimoiety terms (wuthurrul wutyurru) is also a section term around the Queensland rainforest region (north-east Queensland), which will be further investigated in this chapter.

Table 29: South-east Cape York Peninsula sections.

a. Wakura, Tjankun, Waniura, (Um)babaram (Sharp 1939)

\begin{tabular}{|l|l|l|l|}
\hline A Kupandji & B Worpu & C Djilandji & D Karpandji \\
\hline \multicolumn{4}{|l|}{ b. Mutju, Ngaikungo, Tjirbal, Mamu, Ngatjan (Sharp 1939) } \\
\hline A Kupandji & B Djikandji & C Djilandji & D Karpandji \\
\hline $\begin{array}{l}\text { C. Warkeeman (Wakiman) includes Booberam (Mbabaram¹), Shanganburra (Jangun), } \\
\text { Kookoowarra, Mularitchee, Chungki and Koochulburra (Mathews 1899) }\end{array}$ \\
\hline A Koopungie & B Cheekungie & C Kellungie & D Karpungie \\
\hline
\end{tabular}

${ }^{1}$ Dixon (1991) referred to Mathews on Mbabaram but does not list any section terms in the vocabulary.

Source: Mathews (1899, p. 251) and Sharp (1939, p. 442).

The themes of some of these moiety names, such as the contrasting bees, are considered in the next section.

6 Wuthurru / wutyurru has been reported as having the meaning 'eagle hawk' in the Warrungu dictionary (Tsunoda 2003, p. 112), but the rest of the entry casts doubt on this. Here, as is commonly found, consultants may give the leading totemic animals when glossing a social category, or the relevant social category when glossing an animal. See also the mention of this term as a matrimoiety in Queensland in Chapter 6. 


\section{Hypothesis That Sections Arose from the Combination of the Same Kind of Moiety or Phratry}

The origin of subsections has taught us that a new and more complex structure does not necessarily eventuate through a combination of different systems-logical as that may seem in the abstract world of theory. A leap to a new level of complexity can occur because the same or similar kinds of social grouping in a region enter into an interaction that produces the new system. In the case of two systems with sections, the interactions that led to subsections were a kind of regular marital exchange between different groups that originally possessed sections with different terminologies. This hypothesis is based on evidence of the structural positions of the old section terms of the two component groups within the new subsection system.

There is evidence- - not as strong as that in the case of subsection originthat at least some of the major section systems in Queensland arose from a similar combination of two systems of the same kind: patriphratries and patrimoieties. The two systems did not join in an abstract way but through a connubium or regular marriage exchange between two groups who were neighbours. Mathew (1910a; 1910b, p. 140) also suggested that 'the multiplication of classes from two [moieties] to four [sections], and four to eight [subsections] was due to an amalgamation of tribes'?

In regard to subsection origin, it is clear that such a marital exchange and system transformation did not occur in every instance when two groups met up. For subsections specifically, it probably occurred only once-or at most, a handful of times involving mutual influence-in a restricted area west and east of Katherine in the Northern Territory, and diffused from there. In cases in which section systems with different terminologies met up across Australia, nothing as momentous occurred; rather, the neighbouring groups simply arrived at a 'pragmatic equivalence' of section terms and practised a system of the old kind between them, although with intertranslatable terms.

7 Mathew's idea of tribal amalgamation lacks evidence, although it is couched in terms of his hypothesis that people resembling 'Dravidians' and 'Veddahs' migrated into north-east Queensland, spread south and 'absorbed the inferior autochthones'. The idea is far-fetched, and even Mathew (1910b, p. 140) was doubtful about it as a hypothesis of section origin. Recent genetic research (Pugach et al. 2013) has bestowed some slight credibility on such ideas of South Indian migration into Australia in the mid-Holocene. 
It appears likely that a similar scenario played out in the origin of sections. In most cases whereby moiety and/or phratry systems were in contact, they established pragmatic equivalence (if they were of the same kind-matrilineal or patrilineal). However, in some instances, the regular marriage exchange produced a new system: the section system. At this stage, we cannot be sure if this occurred once in one region, as is proposed for the subsection origin. We examine a region where perhaps a number of such section origins might have occurred. Similar conditions might have provoked the same kind of process in several places. However, it seems most likely that this single or multiple origin of sections took place in Queensland.

One particular idea in respect to the origin of sections that had currency in the late nineteenth century was that they might have arisen from some kind of local descent grouping, such as a clan or phratry (group of clans). This is somewhat similar to, or could be viewed as virtually the same as, the hypothesis that they arose from two neighbouring groups in contact, as in the cases to be considered on the east coast of Queensland. Since sections are not local (tied to places or areas) or co-residential like patriclans or patriphratries, it is hard to imagine how one could have arisen from the other. However, there are possible pathways in Australia that could be investigated, as well as in the Panoan region of South America.

I review the patrimoiety system terminologies of north-east Queensland in the next sub-subsection. In most instances, the moieties were named after species of bees or species of large birds (usually eagles). I move on to a case in sub-subsection 'Roth and Howitt on the Annan River Tribe', in which a section system apparently emerged from the coming together of two such systems in neighbouring groups in an area north of Cairns, as reported by Roth (1904) and Howitt (1904) at the turn of the twentieth century. Another similar process may have also occurred on the Queensland coast, farther south near Mackay, which is also described. In the subsection 'Sections in the Mapoon Area, North-Western Cape York', another possible example of an emergence of sections or sectionlike groupings on the north-west coast of Cape York Peninsula near Mapoon is analysed. 


\section{The Eagles and Bees Patrimoieties in North-East Queensland}

In order to understand the origin of sections in this region, it is necessary to understand the patrimoiety systems that preceded sections and the contrasting natural species that provided their names. There are a number of groups with patrimoieties named after a pair of contrasting bee species.

In the north-east Cape York Peninsula, the forms are Kuya- and Karpa-.

The form karrpa- is replaced by kapa- in languages further south, such as the widespread Maric subgroup and neighbouring languages. Terms beginning with $k a p a$ - are also very widespread in the remainder of coastal Queensland as terms for a honey bee species and a matrimoiety instead of a patrimoiety. ${ }^{8}$

The term kuya also has variants kutya and kurtya, which are probably the older forms before the loss of $r$ and lenition ${ }^{*} t y>y$. In some languages, either karrpa-/kapa- or kurrtya-/kutya-/kuya- are glossed as a native bee in general, rather than a species. However, in some of these cases, this could be a question of the most abundant species in the region providing the generic hypernym (McConvell 2002). In many languages, these two terms name separate species of bee. ${ }^{9}$

For instance, based on fieldwork around Brisbane and on Stradbroke Island, Hockings (1884) identified a form kaapay (which he spelled 'karbi') as Trigona carbonaria, a small black bee that is now known as Tetragonula carbonaria. This form is undoubtedly related to the northern form for the same bee karrp+ and many other central and southern Queensland forms kapa+. This bee was named T. hockingsi; however, recent research has failed to find distinctive differences between $T$. hockingsi and T. carbonaria. Dollin et al. (1997) noted that there is no distinct difference between T. carbonaria and T. hockingsi in coloration, pilosity or structure'-although there are differences in brood structure.

8 Barrett (2005, Appendix E64) reconstructed *kapa as Proto-Maric 'honey, bee' and this may well be an inheritance, although the possibility of internal diffusion within Maric should not be ruled out. Laffan (2003, p. 105) reconstructed *kapay 'honey, honey-bee' for Proto-Waka-Kabic and *kapa for the subgroup Waka.

9 Kurrtyala/kurrtyala/kuyala (and possibly the QG section term kurrkila) are also associated with (kinds of) eagle, but these seem to be unrelated despite their similarity. See the next section. 
The other slightly larger bee with yellowish markings, Hockings was told, was known as kutya around Brisbane (which he spelled 'kootchar'). From Hockings's (1884, p. 153) description of the external tube entrance to the nest, this bee was identified in later research as the Austroplebeia australis. This form descends from Proto-Wakka-Kabic *kutya 'honey' (Laffan 2003, p. 124) and is related to kurtya, kutya and kuya in northern Queensland. ${ }^{10}$

T. carbonaria and $A$. australis are the two species that name the opposite moieties in northern Queensland. T. carbonaria is predominantly found in the inland and $A$. australis is found in the coastal areas (Halcroft et al. 2013; Hockings 1884, p. 153; see Figure 25).

In south-east Cape York Peninsula, the patrimoieties are commonly Walarr: Tapu. These names are also contrasting bee species. In Kuku Yalanji, tapu is a 'small dark bee, nests in trees' (Herschberger \& Herschberger 1986), which is probably $T$. carbonaria, and walarr is another bee speciesperhaps $A$. australis. These bee names form part of the social category system of the neighbouring group speaking a dialect very similar to Kuku-Yalanji-Kuku-Nyungkul—called the 'Annan River Tribe' by Roth (1904) and Howitt (1904).

\section{Roth and Howitt on the Annan River Tribe}

While not claiming to have discovered the origin of sections, Howitt (1904) did make some relevant points about the section system among what he calls the 'Annan River Tribe', better known as Kuku Nyungkul, a close affiliate of the Kuku-Yalanji in the Daintree Forest area of southeast Cape York Peninsula. Basic information was supplied to him by Roth (1904). Howitt omitted an important point made by Roth in that the group spoke 'a mixture of Koko-Yerlantchi [Gugu Yalanji, on the south side] and Koko-yimidir [Guugu Yimidhirr, on the north side]'-I return to this point later. Figure 26 is a map of the location of Kuku Yalanji and Guugu Yimidhirr. ${ }^{11}$

10 The referent species is likely to be Austroplebeia australis.

11 Haviland (1979, p. 29) also recorded that the Annan River people spoke an 'intermediate dialect' with features of both Guugu Yimidhirr and Gugu Yalanji, which was regarded with disdain by more central speakers of these languages; it was called Gugu Buyun 'bad language' in Yalanji and Guugu Yiirrurru 'mumbling talk' in Yimidhirr. 


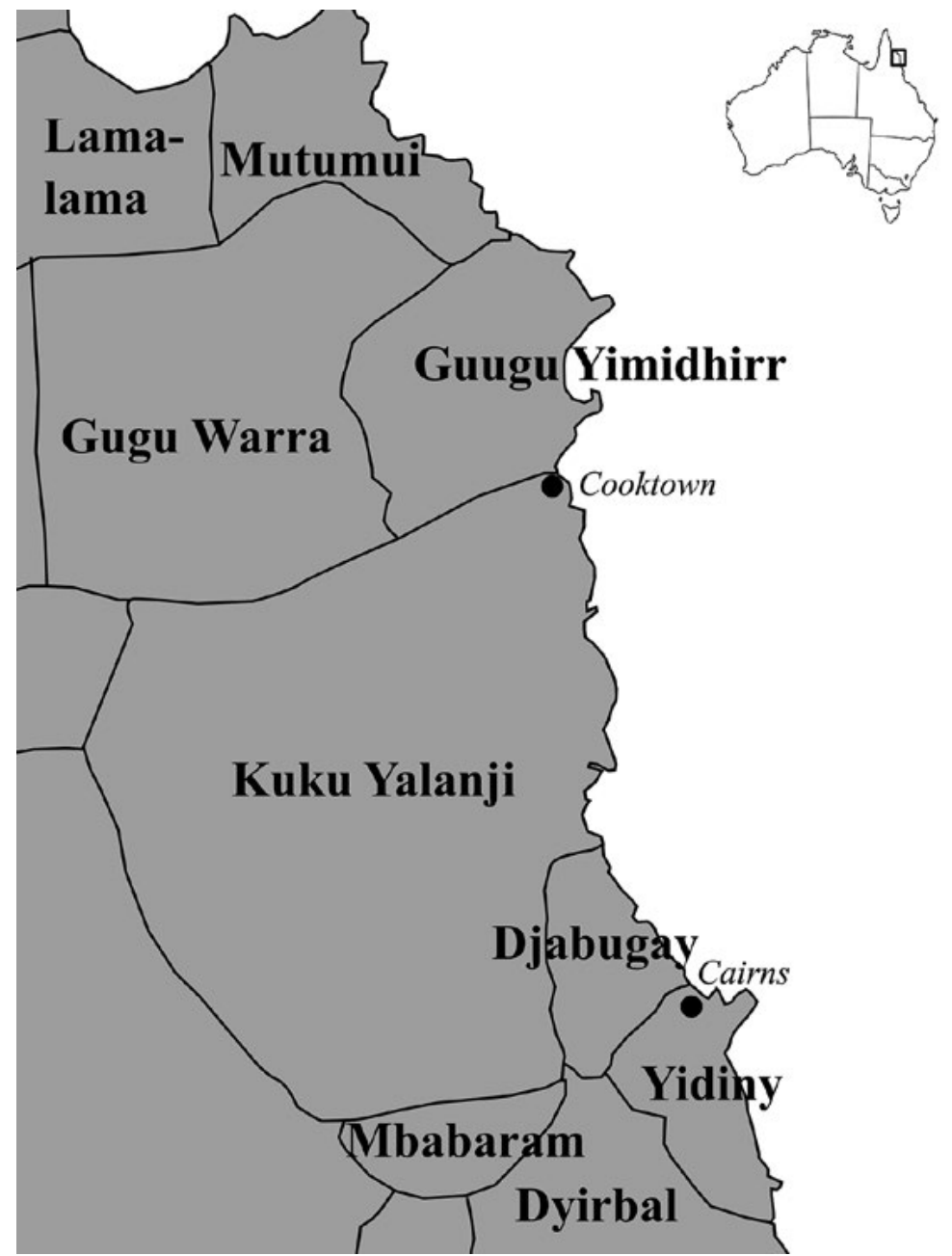

Figure 26: Map of the location of Kuku Yalanji and Guugu Yimidhirr.

Source: Adapted from austkin.net.

Howitt (1904, p. 118) gave the patrimoiety and section terms shown in Table 30. I have added the origin in the two neighbouring languages, Gugu Yimidhirr (GY) in the north and Kuku Yalanji (KY) in the south, which aligns in language provenance with the moiety species names. This is discussed further in the following sections. 
Table 30: Annan River moieties and sections.

\begin{tabular}{|l|l|l|l|}
\hline Patrimoieties & & Sections & \\
\hline Murla a bee & GY & Jorro a bee & GY \\
\hline & & Kutchal saltwater eaglehawk & Not KY \\
\hline Walar a bee & KY & Walar a bee & KY \\
\hline & & Wandi eaglehawk & KY \\
\hline
\end{tabular}

Source: Adapted from Howitt (1904).

Roth (1904) stated that the Walar bee was identical to the $d u$-ar bee of the 'Bloomfield blacks' (KY), and Murla, a different species, was the same as the tabu (elsewhere spelled dabu) of the Bloomfield (KY) and the jorro of the McIver River (GY). Roth provided pragmatic equivalences with the QG section system, as is illustrated in Table 31 .

Table 31: Pragmatic equivalence of Annan River and Queensland General sections according to Roth and Howitt. ${ }^{12}$

\begin{tabular}{|l|l|}
\hline Annan River & Queensland General Sections \\
\hline Walar & Wungko $[$ Wunku] \\
\hline Wandi & Kurkilla [Kurrkila] \\
\hline Jorro & Kupuru [Kuparu] \\
\hline Kutchal & Banbari [Panpari] \\
\hline
\end{tabular}

Source: Based on Howitt (1904, p. 140) and Roth (1904).

This set of equivalences implies the following marriage and descent relationships among the Annan River sections (see Table 32) based on the QG system (see Table 33). The arrangement in the tables is not the familiar one used by Radcliffe-Brown (1931) in which the columns are covert matrimoieties $\mathrm{AC}$ and $\mathrm{BD}$. Rather $\mathrm{C}$ and $\mathrm{D}$ have been permuted, so that the columns are the patrimoieties AD and BC (the Murla or Jorro bee and the Walar bee respectively). This change has been made to accommodate the importance of the patrimoieties in the area of north Queensland under discussion here. ${ }^{13}$

12 Sharp (1938-9, p. 268) reported: 'Koko Yerlandji (Kuku Yalanji) informants disclaimed a four section system, although Roth (1910, p. 100) ascribes to them an organization of that type; however, since my informants were southern members of the tribe, it is possible that the northern Koko Yerlandji, with whom Roth came in contact, do have sections similar to those of their neighbours to the west and north'.

13 It is worth noting that the $\mathrm{C}$ section of QGS has an etymology that may link it to an eagle species, mirroring the species alignment of Annan River C, although not the form. 
Table 32: Annan River sections.

\begin{tabular}{|l|l|l|l|l|}
\hline Code & Terms & & Code & \\
\hline A & Kutchal (Kurrityal) eagle sp. & Marry & B & Walar bee sp. \\
\hline & father/child of & & & father/child of \\
\hline D & Jorro (Dhurru) bee sp. & Marry & C & Wandi eagle sp. \\
\hline
\end{tabular}

Source: Based on Roth (1904) and Howitt (1904).

Table 33: Queensland General section terminology.

\begin{tabular}{|l|l|l|l|l|}
\hline Code & Terms & & Code & \\
\hline A & Panpari & Marry & B & Wunku \\
\hline & mother/child of & & & mother/child of \\
\hline D & Kuparu & Marry & C & Kurrkila \\
\hline
\end{tabular}

Source: Author's work.

The covert matrimoieties in the Annan River system (A-C and B-D) align with eagles and bees respectively. The patrimoieties, which are the overt type of moiety in the north-east Queensland region, have an arrangement in which each moiety has a bee species for one section and an eagle species for the other. The patrimoiety names in the region are generally contrasting types of bees, or contrasting types of birds, so Annan River stands out as distinct in this respect. ${ }^{14}$

Howitt (1904, p. 118) remarked:

This [Annan River] system is peculiar in that the classes [moieties] and subclasses [sections] have animal names, and are apparently totems, which as before mentioned, is a rare occurrence. In the tribe descent is in the male line, for instance, the children of a man who is, say Murla-Jorro is MurlaKutchal. (emphasis added)

If we compare this to a relatively recent recording of the Kuku Yalanji lexicon (Herschberger \& Herschberger 1986; including some Kuku Nyungkul), the items in the Walar (Walarr) patrimoiety are present with approximately the same species meanings that were recorded by

14 This harmony in the (covert) matrimoiety composition and lack of it in the overt patrimoieties is reminiscent of the study by Alain Testart (1978) in which he showed similar harmony between matrimoieties and the matrilineal totemic group species names of which they were composed, and in contrast the lack of harmony between the totems that belonged to patrimoieties. He proposed a hypothesis that patrimoieties and patrilineal descent replaced matrimoieties and matrilineal descent in various regions of Australia, but that the totemic animals remained attached to the moietiescausing a lack of coherence. 
Roth (1904) and Howitt (1904). Walarr (which is both a patrimoiety and section term) has these three senses according to the Kuku Yalanji dictionary:

1. Whiskers, beard ${ }^{15}$

2. Name of one of the tribe moieties

3. Type of honey bee almost like the dabu (other moiety), but bigger and nests in trees.

Dabu is defined in the dictionary as a 'small black bee with a light sting' that also nests in trees. None of these bees actually sting, although T. carbonaria does defend itself by biting, as observed by Hockings (1884, p. 151).

The walarr: dabu patrimoiety division is spread widely across this region and the referents are clearly the two honey bees-identified as T. carbonaria and $A$. australis respectively. They are commonly referred to as black and small, versus yellow and larger respectively, and belong to the forest and coastal regions respectively, as opposed to the 'scrub' of the inland. Similar physical and ecological characteristics apply to the bees named $k a(r r) p a-$ and kurtya-/kutya-/kuya- respectively to the north and south. Whether the species identification is the same in all cases requires further research.

In neighbouring areas, the name of the two patrimoieties is also taken from these two species of bees; however, the linguistic form of the names is different, as will be further discussed. ${ }^{16}$

The other term for a section in the Walarr moiety, Wandi, translated to 'eagle-hawk' by Howitt, is glossed in the Kuku-Yalanji dictionary:

Fish hawk, brown hawk, red-backed sea eagle.

One of the sacred birds.

Whether these are different species or different English terms for the same species is not clear. 'Red-backed sea eagle' is a common term for the Brahminy Kite (Haliastur indus). Howitt's (1904) and Roth's (1904) term 'eagle-hawk' may apply to this bird or a class of large raptors.

15 Note that the term wurripa in Gugu-Badhun and Warrungu has a referent as a bee 'with a beard'. Walarr in Guugu Yimidhirr means 'beard, stubble, moustache' (Haviland 1979, p. 172).

16 Other species also play a role as moiety emblems, based on the Kuku Yalanji dictionary. For instance, the term for 'hornet, paper wasp', wurpu, rendered as worbu in earlier sources, is a section term in Mbabaram and Gugu Djangun, not far from Kuku Yalanji and a patrimoiety in groups to the north, where it is said to be a term for a bee species. 
One striking feature of the arrangement in this moiety is that the moiety term and one component section are the same: Walarr. We will return to a discussion of this later. While the terms in the Walarr moiety are clearly recognisable as animal species in Kuku Yalanji, the same is not true of the other moiety, as described by Howitt (1904). The section term Kutchala [sic], said to mean 'salt-water eagle-hawk', is not found in the dictionary, with this or any other meaning. However, there is a very widespread root for wedge-tailed eagle (Aquila audax), kurrityal(a), throughout the northern Queensland languages, northern Maric and some languages west of Maric, including Mayi, and penetrating into Arandic (Alpher 2004). A related form for the same bird-mainly kutyalalkuthala but with some variation-is found in Yidiny, south of Kuku Yalanji (kuyal[a], Dixon 1991, p. 158), and in southern Maric. The term cited by Howitt (1904) for Kuku Nyungkulkutyal or possibly kurtyal -is no doubt a form of this root; whether it means 'wedge-tailed eagle' or 'sea eagle' (Haliaeetus leucogaster) in this area is unclear. It seems that this term did not originate as an 'eagle' term in either Kuku Yalanji or Kuku Nyungkul, but was borrowed primarily as a section term from another neighbouring language. ${ }^{17}$

The other two terms in the opposite moiety to Walarr-bee terms Murla for the moiety and Jorro for the other section-are also not native to Kuku Yalanji. As previously mentioned, Roth (1904) also regarded the terms for sections in this moiety as foreign in origin-for instance, jorro as belonging to the McIver River, which is Guugu Yimidhirr country. This is undoubtedly Guugu Yimidhirr dhuru, glossed as 'native bee species' by Haviland (1979, p. 174)—possibly A. australis. Murla is Guugu Yimidhirr mula 'sugarbag; bee (generic)' (Haviland 1979, p. 174). Alpher (2004) interpreted this as Proto-Paman, but it is variable in meaning in different languages (e.g. 'blood', 'paint' and 'honey').

In more recent times, according to the Kuku-Yalanji dictionary, the other moiety term $D a b u$, which is a bee term, refers to:

1. Small black bee which nests in trees, has a light sting

2. The honey from this bee

3. The name of one of the clan moieties.

17 Kurrityala is found as the term for wedge-tailed eagle in the neighbouring rainforest languages, as well as more widely in Biri (Terrill 1993, p. 210) and Kongulu (between the Mackenzie River and the lower Dawson where it is an eagle totem name 'kurithulla'; Howitt 1904, pp. 111-2); and in the form kutyala in a number of Maric languages. In Guugu-Yimidhirr, the gudha is a 'black bee', probably T. carbonaria. This term is related to other widespread bee terms in Queensland but not to eagle terms. 
This is most likely T. carbonaria.

The section system described by Howitt (1904) may have been a fleeting episode in building such a system, or at least a system that did not last very long. However, it does show how the building blocks of a section system can be put into place in this case and perhaps more generally. Two different ethnic groups with patrimoieties began an interaction and type of exchange. The groups may well have been Gugu Yalanji/Gugu Nyungkul to the south and Gugu Yimidhirr or some subgroup thereof to the north. When we consider the information from Roth (1904) that the group with this system was bilingual in these two languages, it would make sense that the terms in one patrimoiety were drawn from one language and the terms in the other were drawn from the other language. ${ }^{18}$

The origin of the Annan River sections could have eventuated as depicted in Table 34. This is, of course, conjectural, but it is important to put forward a hypothesis to see if further evidence gathered both in this region and elsewhere can support it. Recent names of moieties and sections are used to exemplify the process:

- Stage I: Separate bee and eagle patrimoieties/patriphratries in neighbouring groups. It has been noted that in most of the region, the division between moiety names is between two contrasting species of bee or eagle-one associated with the coast and one with the inland. It is assumed that this was also the original arrangement in this part of north Queensland.

- Stage II: Language group exogamy and pragmatic equivalence of moieties marriage. In this stage, two neighbouring groups practise patrimoiety exogamy and recognise equivalence of each other's moieties. Marriage continues to be both within and between groups.

- Stage III: Marriage with other language group and children assigned to equivalent moiety of own language group. Marriage shifts decisively towards exogamy between language groups, while maintaining moiety exogamy; thus, the preferred marriage is only with a partner of the opposite moiety and other language group. Additionally, patrifiliation places a child of a father in the equivalent moiety of the other language group, in which his father would have normally originated. This sets the stage for the establishment of four sections.

18 Elsewhere in northern Australia, one patrimoiety is regarded as 'local' and one as 'foreign', as in the case of Yolngu Dhuwa and Yirritja respectively. 
- Stage IV: Moieties become mixed as to species. This stage brings the marriage rule in line with practice by making the spouse category the one that is formerly determined by the moiety system of a different language group. This leads to each moiety containing one eagle section and one bee section.

- Stage V: Development of sections. The typical structure and functioning of the sections system are achieved.

Table 34: Hypothesis about the origin of Annan River sections.

\begin{tabular}{|c|c|c|c|c|}
\hline \multicolumn{5}{|c|}{ Stage I: Separate bee and eagle patrimoieties/patriphratries in neighbouring groups } \\
\hline & 'Inland' moiety A & & \multicolumn{2}{|c|}{ 'Coastal' moiety B } \\
\hline $\begin{array}{l}\text { Southern } \\
\text { language group } 1\end{array}$ & Kurrityal eagle sp. & marry & \multicolumn{2}{|c|}{ Wandi eagle sp. } \\
\hline $\begin{array}{l}\text { Northern } \\
\text { language group } 2\end{array}$ & $\begin{array}{l}\text { Dhuru bee sp. } \\
\text { A. Australis } \\
\text { [Inland, larger yellow] }\end{array}$ & & \multicolumn{2}{|c|}{$\begin{array}{l}\text { Walarr bee sp. } \\
\text { T. Carbonaria } \\
\text { [Coastal, smaller, black] }\end{array}$} \\
\hline \multicolumn{5}{|c|}{ Stage II: Language group exogamy and pragmatic equivalence of moieties marriage } \\
\hline & 'Inland' moiety A & & \multicolumn{2}{|c|}{ 'Coastal' moiety B } \\
\hline $\begin{array}{l}\text { Southern } \\
\text { language group } 1\end{array}$ & Kurrityal eagle sp. & & \multicolumn{2}{|c|}{ Wandi eagle sp. } \\
\hline $\begin{array}{l}\text { Northern } \\
\text { language group } 2\end{array}$ & $\begin{array}{l}\text { Dhuru bee sp. } \\
\text { A. Australis }\end{array}$ & & \multicolumn{2}{|l|}{$\begin{array}{l}\text { Walarr bee sp. } \\
\text { T. Carbonaria }\end{array}$} \\
\hline \multicolumn{5}{|c|}{$\begin{array}{l}\text { Stage III: Marriage with other language group and children assigned to equivalent } \\
\text { moiety of own language group }\end{array}$} \\
\hline & 'Inland' moiety A & & \multicolumn{2}{|c|}{ 'Coastal' moiety B } \\
\hline $\begin{array}{l}\text { Southern } \\
\text { language group } 1\end{array}$ & Kurrityal eagle sp. & \multirow[t]{2}{*}{ marry } & $\begin{array}{l}\text { Wandi eagle } \\
\text { sp. }\end{array}$ & \multirow[t]{2}{*}{ Father/child } \\
\hline $\begin{array}{l}\text { Northern } \\
\text { language group } 2\end{array}$ & $\begin{array}{l}\text { Dhuru bee sp. } \\
\text { A. Australis }\end{array}$ & & $\begin{array}{l}\text { Walarr bee } \\
\text { sp. } \\
\text { T. Carbonaria }\end{array}$ & \\
\hline \multicolumn{5}{|c|}{ Stage IV: Moieties become mixed as to species } \\
\hline & 'Inland' moiety A & & \multicolumn{2}{|c|}{ 'Coastal' moiety B } \\
\hline $\begin{array}{l}\text { Southern } \\
\text { language group } 1\end{array}$ & Kurrityal eagle sp. & \multirow[t]{2}{*}{ marry } & $\begin{array}{l}\text { Wandi eagle } \\
\text { sp. }\end{array}$ & \multirow[t]{2}{*}{ Father/child } \\
\hline $\begin{array}{l}\text { Northern } \\
\text { language group } 2\end{array}$ & $\begin{array}{l}\text { Dhuru bee sp. } \\
\text { A. Australis }\end{array}$ & & $\begin{array}{l}\text { Walarr bee } \\
\text { sp. } \\
\text { T. Carbonaria }\end{array}$ & \\
\hline
\end{tabular}


Stage V: Development of sections

\begin{tabular}{|l|l|l|l|}
\hline & Patrimoiety A/D & & Patrimoiety B/C \\
\hline & $\begin{array}{l}\text { A Kutchal (Kurrityal) } \\
\text { eagle sp. }\end{array}$ & marry & B Walar bee sp. \\
\hline & father/child of & & father/child of \\
\hline & $\begin{array}{l}\text { D Jorro (Dhuru) bee } \\
\text { sp. }\end{array}$ & marry & C Wandi eagle sp. \\
\hline
\end{tabular}

Source: Author's work.

\section{Origin around Mackay on the Queensland Central Coast}

Another section system that shows signs of having developed from the interaction of two patrimoiety systems is that of Guwinmal, reported as Kuinmurbera by Roth (1898). This terminology differs from others that we have mentioned so far in Queensland and has a restricted range on the central coast. The section system is set out in Table 35 (presented in the same way as Table 34), aligning the patrimoieties in columns rather than matrimoieties, but retaining Radcliffe-Brown's (1931) coding. Note that $-a n$ is a version of a common feminine suffix in the region $(-k a n)$.

Table 35: Kuinmerburra, also known as Guwinmal.

\begin{tabular}{|l|l|l|l|}
\hline $\mathrm{Am}$ & Karilburra & $\mathrm{Bm}$ & Koorpal \\
\hline $\mathrm{Af}$ & Karilburran & $\mathrm{Bf}$ & Koorpalan \\
\hline $\mathrm{Dm}$ & Kooealla & $\mathrm{Cm}$ & Moonal \\
\hline $\mathrm{Df}$ & Kooeallan & $\mathrm{Cf}$ & Moonalan \\
\hline
\end{tabular}

Source: Mathews (1898, p. 333).

D kuyala is close to the northern Queensland bee moiety term kuya-, which has been previously mentioned. ${ }^{19}$ The complementary section term in the same patrimoiety karilpurra has a resemblance to the rainforest A section karpawuru (see the section 'The Queensland General Section System') and to north Queensland and more widespread terms for moieties and honey bee contrasting with the kuya moiety/species. Kurpais a widespread section and matrimoiety root, and the section term kupuru in the QG section system will be discussed. Less familiar is the term munal, which was recorded by Roth (1898) as mannal (manal).

19 It also has a resemblance to the form of the eagle moiety term found in Yidiny kuyala; however, the latter is restricted to this language and probably the result of a local and isolated lenition * $t y>y$. Roth (1898) also recorded at Rockhampton and Yeppoon the section terms koo-da-la; koor-pal; karal-be-ra; mun-nal, with kuthala rather than the lenited kuyala-the latter attributed to the Torilla, Pine Mountain, dialect. Roth aligned this to the QG term koorkkilla (kurrkila); see the next section. 


\section{Sections in the Mapoon Area, North-Western Cape York}

In Australia, Roth (1910) was a champion of the idea that sections might have arisen from local groupings such as clans, and claimed that 'sections' around Mapoon in Cape York were local groupings. Mathews (1900) also made a similar claim. As Thomson (1934, pp. 222-6) explained, the authors' information came from Reverend N. Hey and it contained a number of errors. The ethnography and linguistic analysis of Roth and Mathews has also been questioned by Crowley (1981).

It seems doubtful that the marriage and descent patterns between the four named groups identified were truly section-like. Thomson (1934, p. 224) stated that 'sections' were not found among the group, who he labelled 'Tjungundji', in question. However, there are 'four groups with names derived directly from the cardinal points of the compass ... to one of which each of the clans belong ... according to its geographical position in relation to each other'. To this extent, Thomson agreed with Roth (1910) in that these groupings, which should properly be called patriphratries, were 'named after separate localities', although the actual names in Thomson's account diverge from those of Roth and Mathews. ${ }^{20}$

Thomson (1934) mapped the nine clans of the Tjungundji, as shown in Figure 27.

Unfortunately, the distribution of the clans across the patriphratries is not recorded on the map or elsewhere in the article. Thomson (1934) noted that both the patriclans and the patriphratries were exogamous. Further, according to Roth (1910, p. 104), by the time he recorded them, these patriphratries were functioning as sections - that is to say, there was not only exogamy but a positive preference for marriage with a particular other phratry, and a rule of filiation not to the father's phratry but to another phratry.

20 Sharp (1939) endorsed Thomson's (1934) account on the basis of his independent investigation in the region. Thomson interpreted the earlier writers as mistaken, but this is not necessarily the case. Three of the four names of the phratries are clan names (Thomson 1934, p. 225); however, it is quite possible that a clan name might be used for a higher taxonomic level, alongside a geographical nomenclature (Thomson 1934, p. 222). 


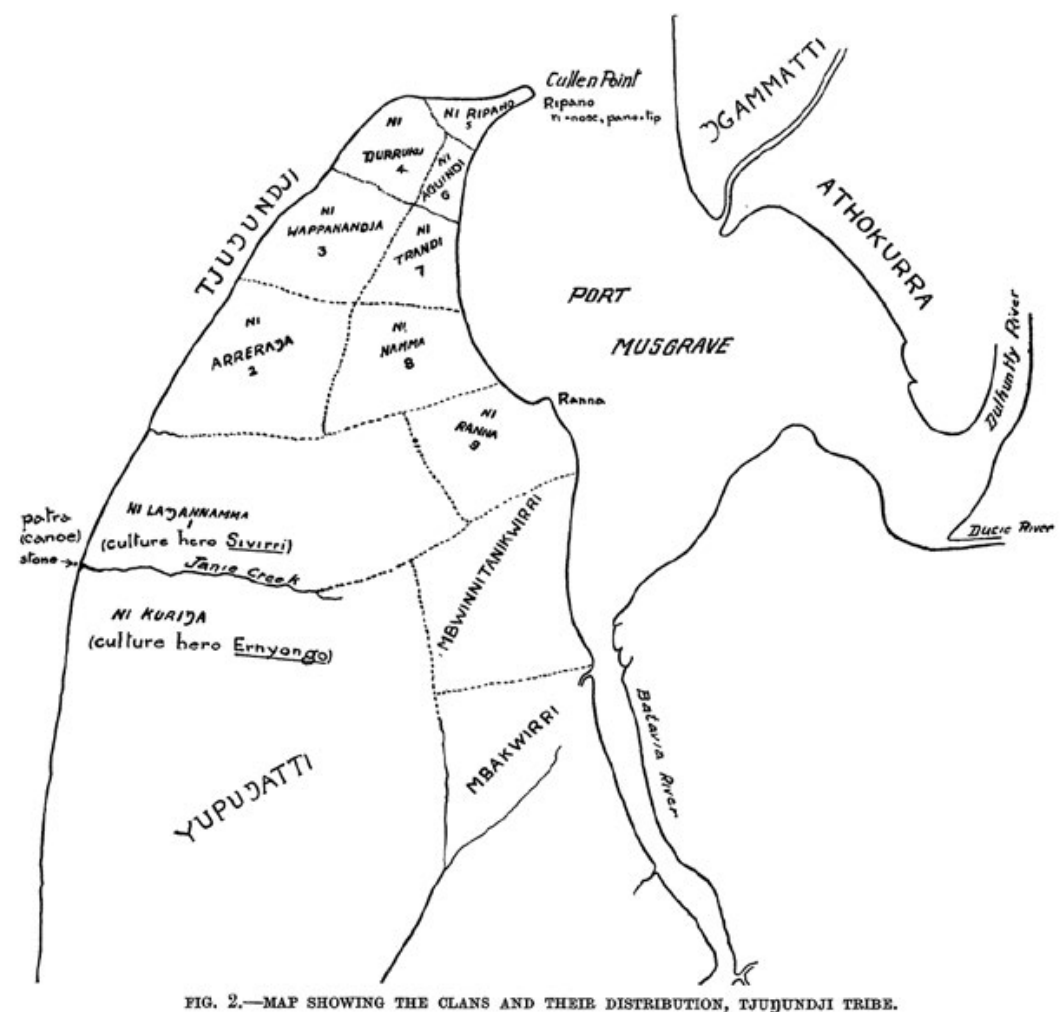

Figure 27: Clans of the Tjungundji.

Source: Thomson (1934, p. 220).

The hypothetical transition could have been the same kind as that diagrammed in Table 34 for Annan River, except that patriphratries were the initial building blocks. Overt moieties are not known to have been present in this area and may not have been strictly necessary to trigger the process that led to sections. ${ }^{21}$ Descent is within the male's phratry-that is, children inherit their father's phratry and country initially; however, this could have had marriage and filiation rules added that might have yielded something like a section system. ${ }^{22}$

21 There is evidence that patriphratries were a form of organisation prior to sections in other parts of the country; see Chapter 7 for the case of Western Australia.

22 This is of course hypothetical, as the existence of section-like operations in the Mapoon area is denied by reliable investigators some 35 years after its first observation. Shapiro (1967, p. 466) proposed that among the Tjungundji, as described by Sharp and Thomson, 'it seems quite possible that these four groups [phratries] are semi-moieties'. The term 'semi-moiety' is not to be read here in its usual meaning (and criticised by Shapiro) as an overlay on subsection organisation, but rather as localised patriphratries with specific marriage prescriptions between them. 
Thomson (1934) acknowledged that there were four patriphratries, but contended that they were named by the four points of the compass. Unfortunately, he did not state which patriclans (shown in Figure 27) belonged to which of the phratries, or if there were any marriage rules, along with clan and phratry exogamy. As well as challenging the findings of Mathews (1900) and Roth (1910) that phratries operated like sections, Thomson also questioned the names that they published for the phratries, since they were either clan or territory names. This is not a devastating criticism, since it is quite possible for a component clan name, or territory name, to act as a name for the whole phratry.

\section{Summary}

This section has discussed several section systems that show signs of having developed from the interaction of two patrimoiety or patriphratry systems in two neighbouring territories and language groups, including marriage between different countries and the affiliation of a child to its mother's territory. This gave rise to section systems. With the exception of the far northern Tjungundii/Ngerrikudi system around Mapoon, these share a common element of having moiety totems based on two species of honey bee and two species of eagle. These became the source of names for a number of section systems in the region.

\section{The Queensland General Section System}

\section{The Spread of a Section System in the Queensland Interior}

Having explored the probable origin of some section systems in northern and central coastal Queensland, we now turn to a section terminology in the interior, which we call the QG section system. We have already encountered this system as Roth recorded the pragmatic equivalence of it with the Annan River system (see Tables 32 and 33). The QG section system is the most widespread system in Queensland, covering a very large area of interior Queensland, and stretches from just south of Cape York Peninsula in the north to close to the New South Wales border in the south, and close to the east coast in places to far western Queensland. 
Although the terminologies in this system are similar to each other, there are differences that can be analysed to help us further understand the history of the system and how it may relate to other systems.

There is an approximate coincidence of this area and the spread of the Pama-Nyungan subgroup of languages known as Maric-after the common word for 'person' mari (Barrett 2005; Beale 1975). However, I avoid calling this set of sections 'Maric' because that could imply that the sections were inherited along with the languages. As noted, social categories such as sections are usually diffused rather than inherited. In this case, it might be that the section system spread with the languages; however, this needs to be investigated empirically before judgements are made. Thus far, the evidence seems to point to the sections not spreading with the languages.

The QG section system terminology is represented in Table 33. These forms are found with little variation over the whole of area of this set. ${ }^{23}$

\section{Changes in the Forms of Queensland General Section Terms and Their Implications}

\section{Survey}

There are variations in form in some languages that have a bearing on the origin of the terminology and its subsequent diffusion. Those to be discussed include:

- a change from $k$ to ty preceding $i$-affecting the form Kurrkila, producing Kurrtyila in Biri

- a substitution of initial $p$ for initial $k$ in the southern Maric D term Kanpari, yielding Panpari elsewhere

- the dropping of initial consonants (linked to the previous point), especially $k$, in various languages in the south and west and to some extent further north in the QG section system area

23 At the current stage of research, it does seem likely that the code letters do represent pragmatic equivalence with the western sections and between all members of the QG section system (McConvell \& McConvell 2015). Mathews (1905, p. 53) gave an example of the lack of pragmatic equivalence between Muruwari sections and Ngiyambaa/Wayilwan, and there are other examples such as this in NSW and Queensland in systems other than QG-but apparently not those with the QG terminology. 
- the loss of an additional initial syllable thu- in the C term thuwunku in part of southern Maric, yielding wunku elsewhere.

- the fortition of the glide $r$ to the retroflex stop $r t$ in southern Maricfor example, producing marti from mari 'person'. This does not affect the section term panparilkanpari.

From these sound changes and other evidence adduced, it is proposed that the QG terminology system originated in the south of the Maric area, and from there spread east and north. It is also probable that the Maric subgroup of languages spread in the opposite direction from the north-east. The relationship of these two events will be briefly reviewed in the next section.

\section{Kurrkila and Kurrtyila}

Barrett (2005, p. 27) wrote of sound correspondences in Maric:

The sequence gi-rare initially and non-existent intervocalically—has become dyi in the eastern dialects [Biri], an example of a common assimilation of the stop to the following front vowel.

As an example, Barrett (2005, Appendix 2 E42) gave *pikirri 'dream', reconstructed as Proto-Maric and found in southern languages; it is also found in Biri as pithi and other Biri dialects Baradha and Yambina as pityiri. Another example from Barrett (2005, Appendix 2) is A90 * makirra 'clay, paint', reflected as matyirra in Biri and neighbouring dialect Wiri. Gugu-Badhun and Warrungu in the north retain the form makirra. ${ }^{24}$

This is the preferred explanation of the correspondence between the section term Kurrkila in most Maric languages and Kurrtyila in Biri, and implies, following Barrett's reconstruction of ${ }^{*} k$ in this environment, that Kurrkila is the original form.

There is a possible alternative explanation of this variation that is rejected here. There is a regular sound change in a number of north Queensland rainforest languages whereby a $t y$ before $i$ becomes $k$ - that is, the reverse of the above change in Biri. Examples include 'liver' kipa in Girramay, Nyawaygi and Wargamay, which is otherwise very widespread as tyipa in north Queensland and other Pama-Nyungan languages as far away as

24 E02 * piki 'lips' apparently does not undergo this palatalisation, although there is a probable cognate piyi in Wiri. 
Victoria (Alpher 2004). ${ }^{25}$ Another example is 'mother's father' ngaki in the rainforest languages, which is otherwise very widespread as ngatyi and usually reconstructed as Proto-Pama-Nyungan (McConvell 1997, 2013).

The section term Kurrkila is found in the rainforest languages that exhibit this change such as Nyawaygi and Wargamay. These languages do not consistently have the QG terminology but kurrkila occurs as B in all three examples given in Table 36. Dyirbal only has this term shared with the QG section system, but the other terms are from the local north-east system. Nyawaygi additionally has C wunku shared with the QG section system. Wargamay has only one of the north-east terms left-A replaced by wutyurru, which is not a section term of the QG section system but a matrimoiety term mainly associated with the QG section system. This anomaly, which is also found in Warrungu and Gugu-Badhun, is discussed further below.

Table 36: North-eastern (rainforest) sections.

\begin{tabular}{|l|l|l|l|l|}
\hline Dyirbal & A karrpawuru & B kurrkila & C tyikunkarra & D kurkurru \\
\hline Nyawaygi & A kapawuu & B kurrkila & C wunku & D kurkurru \\
\hline Wargamay & A wutyurru & B kurrkila & C wunku & D kurkurru \\
\hline
\end{tabular}

Source: Dixon (1972, p. 31; 1981, p. 513; 1983, p. 5).

If the hypothesis that sections began from interactions of two sets of patrimoieties in neighbouring groups is correct, we might expect to find evidence that the other terms in the QG section system were moieties with original totemic animal meanings. No solid evidence of this kind has emerged thus far, ${ }^{26}$ and may be hard to find due to the time depth of the events and limited amount of data on the languages in the relevant area. We continue here to plot the spread of the QG section system and return later to the broader question of the origin of sections in Queensland.

25 Alpher (pers. comm.) suggested that the Proto-Pama-Nyungan form should be *kipa rather than ${ }^{*}$ tyipa. ${ }^{*} K>$ ty in the environment of a following front vowel would certainly be more common and 'less marked' on a world typological scale; however, the reverse appears to have occurred here. The form kipa 'liver' is also found in Dharumbal (Holmer 1983; Terrill 2002, p. 58) but although this is some distance south from the North Queensland rainforest, in Rockhampton, it does not necessarily support a reconstruction of * $k i p a$ to $p P N y$. Another possibility is a linguo-genetic link between the rainforest languages and Dharumbal. Terrill (1998, p. 87; 2002, p. 15) saw Dharumbal as dissimilar to Biri to the north and Waka to the south. There are other examples of $k$ corresponding to a laminal before $i$-such as kira 'teeth' (kirra?; Terrill 2002, p. 101) whereby thirra and yirra are much more common throughout Pama-Nyungan and tyirra is found alongside yirra in Biri (Alpher 2004).

26 Holmer (1983, pp. 339, 374) reported what appeared to be a patrimoiety system among the Biri with the terms wunku: kangurru. The first of these is also a section term in the QG section system. 
Based on linguistic evidence, it seems probable that the QG section terms panparilkanpari and wunkulthuwunku originated among the southern languages of the Maric subgroup—not necessarily as far from the north as they are now-assuming a spread of languages. Speculatively, these two could have been southern patrimoiety terms, and kupuru and kurrkila the northern moieties (as illustrated in Table 37), who entered into marriage exchange with them; however, there is no direct evidence of this. One might point to the presence of kurrkila in the rainforest languages with different section terms as (albeit weak) evidence of a potential northern origin for the term.

Table 37: Hypothesis about the origin of the Queensland General section system from patrimoiety and country interaction.

\begin{tabular}{|l|l|l|}
\hline Patrimoieties & A/D & B/C \\
\hline North & A kupuru & B kurrkila \\
\hline South & D kanpari/panpari & C thuwunku/wunku \\
\hline
\end{tabular}

Source: Author's work.

An alternative hypothesis is that these QG section system terms might not have come from patrimoieties, but perhaps matrimoieties, will be discussed later in this chapter.

\section{Initial K/P Alternation in South-Western Maric}

A striking variation in section terms is the frequency of $\mathrm{D}$ panpari in the northern and central Maric areas and kanpari in southern Maric (Bidyara and Margany/Gunya). This is not a common type of sound change in any of the languages. ${ }^{27}$ However, although it is not apparently very common in the limited vocabularies that we have available for Maric, it does seem to have some regularity in general vocabulary. ${ }^{28}$

For instance, Breen (1973) cited the term kapu+ (gabu, gabugadhi and gabuwadhi) meaning 'later' in Bidyara; however, other sources have papu in the same meaning in south-western dialects:

- $b a b o$ (C) W. R. Conn in Curr 1887 Upper Warrego and Paroo Rivers

- $\quad b a b o$ (P) L. M. Playfair in Curr 1887 the Upper Paroo ['by and by']

- bobo (H) L. M. Playfair in Curr 1887 the Upper Paroo ['by and by'].

27 Where it does occur, the solution is usually to seek a reconstruction in some intermediate sound such as ${ }^{*} k w$ in Indo-European, which yields $p$ in some languages and $k$ in others. There is no evidence for this kind of solution in this case.

28 Thank you to Tony Jefferies for giving me access to his compilation of Maric vocabularies. 
Obviously, it would be beneficial to find more examples such as this, as well as external cognates of forms that would decide which of the initial consonants is the original. Fitzgerald (1997, p. 162) cited a form kalypu in Bagandji 'by and by, later', which could be a cognate of kapu in Maric. While Fitzgerald mentioned lenition of $l y$ to $y$ before peripheral consonants in another language, there is no cogent justification for loss of $l y$ that I am aware of. If this were firmed up, or parallel examples found, this would strengthen the case for the direction initial ${ }^{*} k>p$ in some southern Maric dialects. Other considerations discussed in the next section do point strongly in this direction.

\section{Initial K-Dropping}

This initial $\mathrm{k} / \mathrm{p}$ alternation in south-western Maric seems to be connected with the widely acknowledged process of loss of initial $k$ in several Maric dialects creating initial vowels. Barrett (2005, p. 21) cited this change in Yandyibara, south of Blackall between the upper Bulloo and Barcoo rivers; however, it actually exists in a number of languages in south-central Maric. In this case, there are intermediate forms of the same root $(a p u+)$ with no initial consonant:

- aboouthy (S) ['by and by']

- aboo (B) ['by and by'].

There is evidence for the direction of this change being ${ }^{*} k>p$. In a list of 90 items collected by Jefferies (2010), 19 alternate \#k and \#zero in different dialects; some have $\# w$; and none alternate \# $p$ and \#zero.

In some languages on the southern edge of Maric such as Gunggari, ${ }^{29}$ which is illustrated in Table 38, but also in the west with Guwamu, the initial dropping affects all the section terms except wunku. However, if we accept the proposal that the original form of $\mathrm{D}$ was kanpari, then this pattern follows the more restricted results of dropping of initial $k$ only.

Table 38: Initial dropping in southern Maric section terms.

\begin{tabular}{|l|l|}
\hline A Upurr [upur?] < *kupuru & B Urrkila < *kurrkila \\
\hline C Wungku [wunku?] < *wunku & D Anpirr [anpir?] < *kanpari \\
\hline
\end{tabular}

Source: Jefferies (2010).

29 These forms displaying an awareness of initial k-dropping are cited by Fison and Howitt (1880, pp. 39-40; see also Gardner \& McConvell 2015, p. 163) from a language named Unghi (Ungkayi), which is undoubtedly a form of Gunggari with initial $k$ lost and ${ }^{*} r>y$. 
In Wakelbura, which may be either Miyan or Yagalingu (Wafer \& Lissarrague 2008, p. 421, fn 276), south of Biri but north of Bidjara, there is a different pattern with $\mathrm{B}$ and $\mathrm{D}$ retaining initial consonants, but A losing the initial $k$ (see Table 39).

Table 39: Different treatment of initial consonants in Maric section terms.

\begin{tabular}{|l|l|}
\hline A Upu $<{ }^{*}$ kupuru & B Kurrkila $<{ }^{*}$ kurrkila \\
\hline C Wunku $<{ }^{*}$ wunku & D Panpayi $<{ }^{*}$ kanpari \\
\hline
\end{tabular}

Source: Author's work.

In accordance with our reasoning, panpari is a later form diffusing from the south to the north after the change ${ }^{*} k>p$ had applied; ${ }^{*}>p$ feeds on ${ }^{*} k>\emptyset$. Kurrkila does not undergo ${ }^{*} k>\emptyset$, as it is presumably a later innovation and initial dropping had ceased in the area by this time.

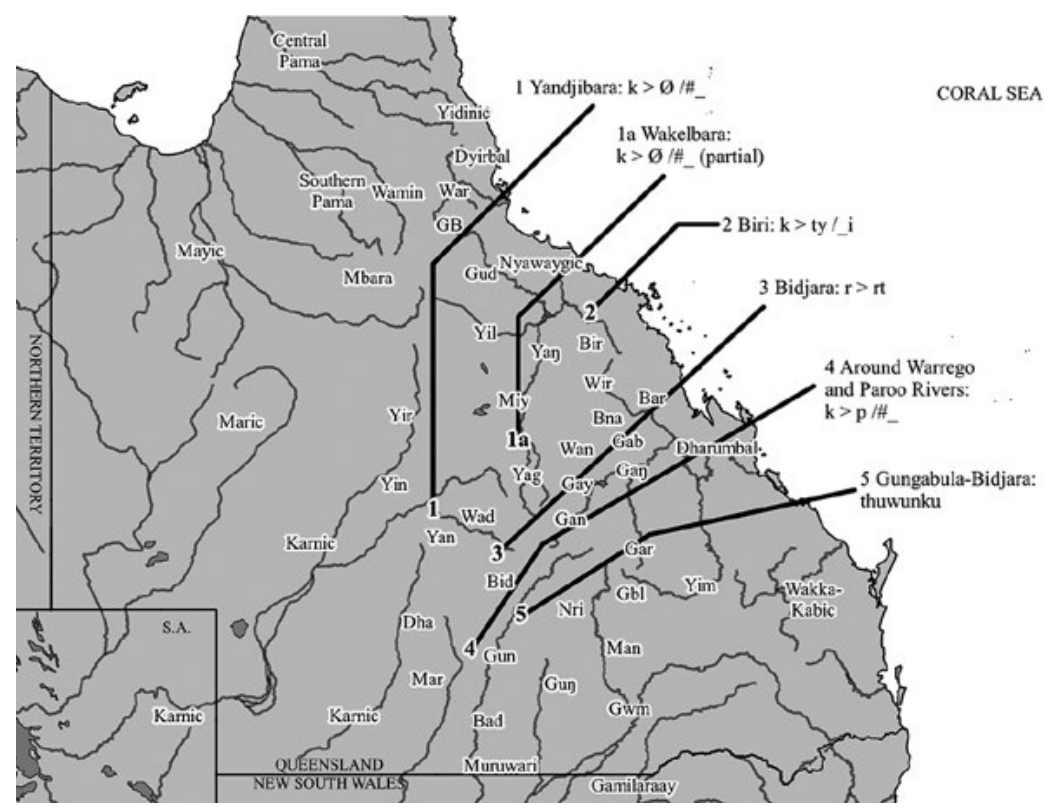

Figure 28: Maric languages with sound changes affecting section terms.

Source: Adapted by William McConvell from Barrett (2005), with location of sound changes by Patrick McConvell. 


\section{Thuwunku/Wunku}

The term wunku is very widespread in QG/Maric; however, in a few languages in the south, the related term has an initial syllable-written $d u$ - or $d$ - (Bidjara and Gungabula respectively; Breen 1972) in sources, perhaps to be interpreted as thu-. Since there are no known prefixes in these languages, the form with three syllables is likely to be earlier. The presence of the form thwunku in one language is witness to a weakening of the initial syllable and probable shift of stress to the second, heralding the loss of the first syllable.

A hypothesis about the origin of the form thuwunku is presented below. The source of the section term thuwunku (which becomes wunku in most Maric languages) is obscure. Perhaps the closest match is the rainforest section term tyikun, which is augmented by an element/suffix -karra. It could be suggested that the $-k u$ in thuwun- $k u$ is a suffix, and that there is lenition of $k>w$ in the former second consonant that becomes the initial after dropping the initial syllable. Initial $k>w$ in the environment of following $u$ is known in southern and central Maric, but there is just one example of $k>w$ in the second consonant (medial) position in Barrett's (2005) vocabulary list. ${ }^{30}$ Further, the fact that the nearest related form of the older form thuwunku in southern Maric languages is far removed to the north-east in another subgroup of languages just outside the Maric border needs to be explained. One might have to look at a scenario in which tyikun was widespread in earlier times, but was replaced in the south by tyuwun, then tyuwunku and then wunku, which diffused across Maric with the QG section system, leaving only a few instances in the rainforest. ${ }^{31}$

30 Barrett (2005, Appendix) B01 *kutyala > wutyala 'bandicoot'; Proto-Maric B13 p-M *kutha > wutha 'nose'; and *kakuparra > kawuparra 'kookaburra' in Biri dialects only.

31 An alternative etymology of thuwunku could be from the 'shade' moiety Dunggu among the Muruwari and neighbouring groups. Roth regarded this as equivalent to the 'blood' moiety Muggulu (Makulu, alternative Makula in Yuwalalaay; Sim 1998). This has the advantage of referring to groups adjacent to the south-western end of Maric, the proposed location of the origin of the QG section system, rather than adjacent to the north-east of Maric; however, the details of 'blood' and 'shade' moieties and the word dunggu are unclear- the latter does not appear in the Muruwari vocabulary in Oates (1988). 


\section{${ }^{*} r>r t$ in Southern Maric}

This sound change of fortition is well attested in many examples and appears to be regular (Terrill 1993, pp. 129-32). Examples can be found in Table 40.

The direction of change is evidently ${ }^{*} r>r t$, since the forms with $r$ are solidly supported as reconstructions in wider protolanguages-for example, *mara 'hand', *kakara 'moon' in Proto-Pama-Nyungan, yuri 'kangaroo > meat' and *puri 'fire' Proto-Paman (Alpher 2004).

Table 40: ${ }^{\star} r>$ rt.

\begin{tabular}{|l|l|l|}
\hline & Bidyara & Biri \\
\hline Man & mardi & mari \\
\hline & $\begin{array}{l}\text { Also, Margany-Gunya } \\
\text { Alpher (2004), cited from Breen }\end{array}$ & \\
\hline Hand & marda & mara *mara PPNy \\
\hline Meat & yurdi & yuri \\
\hline & $\begin{array}{l}\text { Also, Margany-Gunya } \\
\text { Alpher (2004), cited from Breen }\end{array}$ & \\
\hline Moon & gagarda & gagara \\
\hline
\end{tabular}

Source: Based on Barrett (2005) and Jefferies (2010).

In this particular case, it is interesting to note that the sound change did not occur in the QG section terms. Two terms meet the conditions for its application: kupuru and kanparilpanpari; however, neither ${ }^{* *}$ kupurtu nor ** kanpartilpanparti are found in any language.

The significance of this lies in linguistic stratigraphy. If fortition of $r$ is a regular change, as we can infer, and section terms were present in the area at the time when it was operating, then this change would have happened to the sections. As it did not occur, the conclusion can be drawn that the section terms were not in the southern Maric area when the change occurred. This is potentially useful in the search for the chronology of section spread. However, there is currently no item in the lists of words available that is affected by $r$ fortition or susceptible to the change (but has not undergone it), whose referent is datable by history or archaeology. However, this is not to say that no such data exist or could be explored in future. 
The most important lesson from this information is that the Maric language subgroup spread independently of, and earlier than, the QG section system. While some of the general vocabulary would have been later loan words from other languages, the bulk would have been inherited from the Maric protolanguage. In the course of this expansion, some such inherited words changed form in different branches, such as through the fortition of $r$ discussed in this section. Words that had entered the language at the Proto-Maric stage or during early spread and diversification of the subgroup would have undergone this change. However, since the section terms did not undergo this change, they must have entered the relevant languages after the change had stopped operating.

\section{The Linguistic Prehistory of Maric and Its Relation to Queensland General Section System Diffusion}

\section{The Queensland General Section System and the Maric Subgroup of Languages}

Writers have arrived at different conclusions about the origin and path of spread of the Maric languages. Dixon (2002, pp. 682-3) placed the origin on the central Queensland coast near Mackay, moving first in two advances north and west, then finally south, and adduced a Karringbool legend to support a coastal origin. This hypothesis is based on the highest lexical similarity of Maric with northern coastal languages, which I have been calling the rainforest languages (Dixon's H, Herbert River; and Jc, Proserpine-Ngaro and Giya). This implies a longer contact between early Maric and these languages.

Barrett (2005, pp. 112-3) challenged this hypothesis and instead proposed that the early Maric moved towards the coast near Mackay, separating into two groups of related coastal languages in the rainforest and Dharumbal/ Waka-Kabic, which was followed by a southward expansion from the interior homeland around the Burdekin River (the border of the east and north internal Maric subgroups).

As already shown, the QG section terms (or at least two of them) originated from languages that are present today in the very south on the periphery of the Maric subgroup. Diffusion of the sections must have taken a northern direction from there to occupy a large zone. However, both hypotheses regarding the language subgroup spread point to a northern origin (albeit 
differing in detail) and a subsequent relatively recent southern expansion. Evidence cited in the last section shows that the language spread occurred before the sections diffused north.

It may be then that the source of the QG section terms should be sought on the southern borders of Maric. The terms in northern New South Wales and south-east Queensland (Waka-Kabic) do not appear for the most part to be related to the QG section system terms in their formalthough as has been noted, semantic calques (or animal totems) could be involved, rather than borrowing of sound forms of words.

\section{A Possible Role of Southern Matrimoieties in Queensland General Section Origin}

One of the matrimoiety terms in the 'Wangkumarra' system (Eastern Karnic, far north-western NSW, and adjacent to Queensland and South Australia) is kulparra-plausibly connected and pragmatically equivalent to kilparra, a matrimoiety term of western NSW (Mathews 1905, p. 50; Wafer \& Lissarrague 2008; see Chapter 6) and encroaching slightly into Queensland, with a hint at least that these terms may have originated in a term for 'emu'. ${ }^{32}$ These terms may be related to the QG A section term kupuru (variant kuparu) and perhaps the Kuwinmal B section term kurpal. This implies that the QG section system was built at least partially from matrimoieties, contrary to the model of interaction of patrimoieties leading to section origin in north-east of Queensland. More research is needed on these matters.

\section{Summary}

This section has demonstrated how linguistic evidence can show where section terms originated and the direction in which they spread. Somewhat surprisingly, in the case of the QG system, the answer seems to be from the south, close to the New South Wales border. Unlike in the previous

32 Breen (pers. comm. to Wafer \& Lissarrague 2008, p. 420). Barrett (2005, Appendix) reconstructed *kulparri 'emu' for Proto-Maric, although many of the reflexes are kulpari, which indicates that the proto-form may have had a glide $r$. Kilparra and Mukwara to the west of Maric are said to mean 'eaglehawk' and 'crow', but there is some confusion about which is which in different sources. Mathew (1910b) denied that he heard anyone giving animal meanings to these terms, stating that they were merely equivalent moieties to those in the region (Victoria and South Australia) where the moiety terms are literally the words for 'eagle' and 'crow' (see also Chapter 6). 
section, the evidence for a particular mechanism of section origin from a combination of patrimoieties or patriphratries did not amount to much —at least as far as we know.

More generally, the pattern being observed here is not only that language expansion and section diffusion are independent processes, but also that one follows the other and can occur in an opposite direction across approximately the same territory associated mainly within the group of closely related languages/dialects known as Maric. It would be instructive to find out if this kind of pattern - in which a language expands and then at the margin of expansion a new cultural feature is contacted and spreads back as an innovation through the country through which the language initially spread-is known elsewhere.

\section{Broader Perspectives}

\section{Sections and Moieties}

\section{Their Relative Independence}

While anthropological treatments of sections and Aboriginal testimony by and large treat sections and moieties as being part of one systemthe former being halves of the latter-the sets of terms for each do not always go together. For instance, while the QG section system discussed in the last section tends to be found in conjunction with a moiety system made up of the pair of terms wuthurru: yangurru (and some variants, especially of the latter), this set of moiety terms has a wider distribution than the QG section system, extending further north-west and east than the section sets. The two kinds of terminology appear to have diffused to a great extent independently and probably at different periods.

However, the question that most concerns us is the extent to which moiety terms entered into the origin of sections. The case of the north-eastern sections examined in the section 'Section Systems in Queensland' does point to patrimoieties and their terms being involved in section origin through amalgamation of two local groups (perhaps language groups) each with two pairs of patrimoieties participating in a particular kind of marriage exchange and filiation. The patrimoieties in this area are also notable for having a fairly transparent association with two types of moiety totems: bees and eagles; and in some cases amounting to use of two contrasting species terms as the names of the moieties. 
Moieties elsewhere in Queensland are less clearly associated with a pair of natural species; further, there is no real evidence of this in many instances, nor has it been proven that this was the case in the distant past.

\section{The Queensland General Matrimoiety System}

This is the situation with the widespread moiety system wuthurru: yangurru (and variants) ${ }^{33}$ that occupies a wide zone of the interior of Queenslandsimilar to the region of the QG section system, but not necessarily closely connected with the section system historically.

Clearly, the QG moiety system is different from the north-eastern case in other ways as well. It is a matrimoiety system, as compared with the patrimoieties of the north-east. Another contrasting feature is that there is very little evidence of the involvement of moieties in the origin of the QG sections unlike in the north-east. The term wutyurru (a variant of wuthurru), generally a matrimoiety term, does turn up as a section term in a handful of languages in the north-east (Wargamay among the rainforest languages, and Warrungu, a northern Maric language). A preliminary hypothesis would propose that this term was imported into the local section system to replace the A section term karrpawuru (rainforest) or kupuru (QG) in an ad hoc way and does not go back to an early stage of section origin itself.

However, older connections do exist between the linguistic forms and meanings of moieties and sections, which enable us to begin sketching the origins of the section systems in at least some parts of Queensland.

\section{Some Historical Links between the Moieties and Sections}

It has already been mentioned that two of the roots of moiety terms occur as both patrimoieties in the north-east and matrimoieties in the southeast (Waka-Kabic). It was proposed that these reflect totemic associations with two species of bees. The issue of how matrilineal institutions were replaced by patrilineal institutions (or vice versa) has been one that has provoked many scholars of an evolutionist or diffusionist (and usually speculative) turn of mind to spill much ink-I do not intend to add to that pool at this point. This shall be tackled in another publication,

33 Mathew (1910a) claimed to have discovered a meaning for wuthurru/wutyurru 'crow', which is said to contrast with opposite moiety terms such as yangurru, which are said to mean 'white cockatoo'. The data and supposed sound correspondences on which this is based have no validity and should be dismissed. 
building on evidence and more solid work on Australia (such as by Testart 1978) without the baggage of grand theories. For now, I simply note that the linguistic connections mentioned briefly here do suggest that there has been a change in lineality of moieties in Queensland that will have to be taken into consideration in any full account of the origin of sections, and similar patches of patrimoieties amid matrimoieties are found in Victoria (see Chapter 6) and Western Australia.

The two moiety terms that are shared between the north-east and south-east of Queensland are karpi(ya[n]) and kuya(n). The term karrp+ is also found as a section term in far southern $C$ and one of the rainforest languages: $K$ in Gugu Djangun and Mbabaram, and K in Dyirbal. In Gugu Djangun and Mbabaram, -ntyi appears to be a suffix, which occurs with three of the four other section terms. One of these (A) is kupantyi, so the root is likely to be kupa-, which is related to the QG section term kupurulkuparu.

These phenomena do not constitute an argument for a cross-cutting of patrimoieties and matrimoieties as the trigger of section originthe earlier hypothesis that has been rejected here and replaced by the amalgamation of patrimoieties from two neighbouring countries in a new marriage exchange and filiation system. The fact that terms that refer to matrimoieties from another part of the country occasionally became section terms in an already-established section system is not an argument for the hypothesis that sections arose from a combination of matrimoieties and patrimoieties. However, it is possible that a process essentially parallel to that, based on patrimoieties, happened elsewherebased on matrimoieties. This could have been the origin of the QG section system and other section systems in southern Queensland and New South Wales; however, analysis of those processes will have to await another publication.

\section{Sections in South America}

While subsections are an institution unique to Australia, sections are not. There are a number of other examples in different parts of the world that are disputable; however, the section systems in the Panoan family of languages around the meeting of the borders of Brazil, Bolivia and Peru can be counted as a clear example of sections. 
A description and discussion of the Panoan section system appeared 20 years ago in the English-language anthropological literature (Hornborg 1993; Kensinger 1995), and there are some publications in Spanish and Portuguese. David Fleck (2013), a linguist/biologist who lives in the Panoan area, has also published relevant material on this topic.

The picture in different Panoan groups is complex and includes major changes in the history of the groups-both before and after colonisation. A few groups have, and have had for a long time, sections in the sense of having four named social categories, with two in each patrimoiety; of these, Kashinawa (Casinanahua) is probably the best known. Figure 29 shows a map by Fleck $(2013$, p. 8$)$ with my rough overlays. There are marriage rules that require a person to marry a certain other category in the opposite moiety, and filiation rules that place their children in the other section in their own moiety.

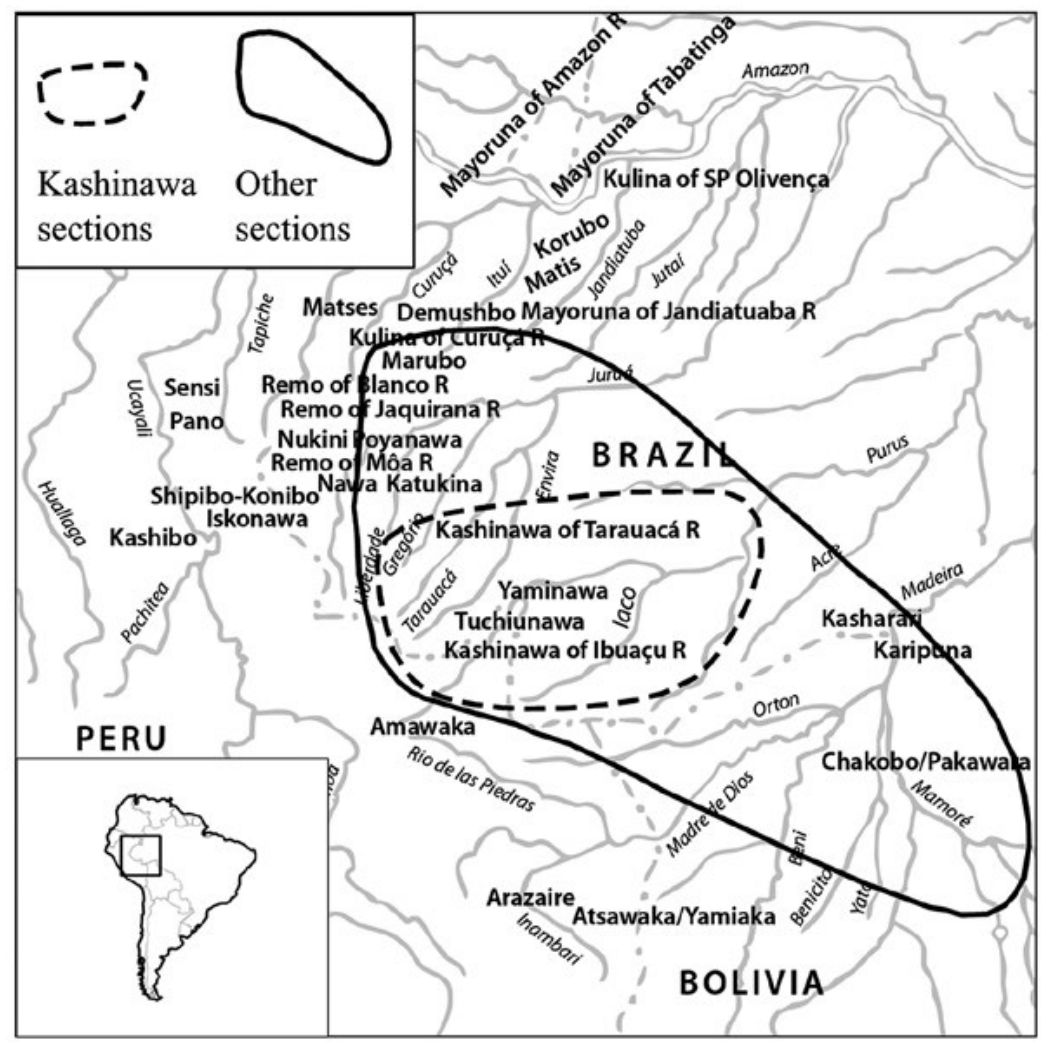

Figure 29: Panoan sections.

Source: Adapted from Fleck (2013). 
This is very similar to Australian sections. The section and moiety names are animal names, which is not so much the case in Australia, for sections at least, although historical enquiry can determine a 'totemic' animal origin of the name in some cases. Not all Panoan groups have sections-some have patrimoieties, or residential or non-residential clan groups, and often the same or similar names are applied to different social groups or categories in different language groups. We have noted a little of this in Australia, in which a matrimoiety term has been used for a section in another place.

One point emerges clearly from the Panoan sections in comparison with Australian sections. Unlike in some areas of Australia, there are no matrilineal moieties, phratries or clans in any of the Panoan areas, so it is highly unlikely that the hypothesis of sections emerging from an overlap of patrilineal and matrilineal institutions would have any justification in this instance. This supports the position adopted that this is not a plausible hypothesis in relation to Australia, where there are matrilineal institutions in some regions.

Further, there is evidence that Panoan sections may have arisen from amalgamation of patrimoieties and local clans or clan-like village groupings in processes that are familiar in South American ethnology, that are often referred to as a type of 'ethnogenesis' (Hornborg \& Eriksen 2011). This seems to parallel the process that was proposed for northern Queensland in 'Section Systems in Queensland'.

Fleck (pers. comm.) was not certain whether sections could be reconstructed to Proto-Panoan, and I share his doubts. Panoan is not a very old family and is estimated to be between 1,000 and 2,000 years in age, although these calculations were done before the outlier Mayoruna was taken into consideration (Fleck 2013, p. 21). While the linguistic comparative method may not be the best way of conceptualising the development of such social category systems, there are other indications that the systems and terminologies of Panoan sections are relatively recent, which will be described elsewhere. While no doubt older than Panoan sections, Australian sections are also relatively recent-originating in the last few thousand years of the late Holocene. The implications of this are addressed in the next section. 


\section{Sections and 'Tetradic Society'}

Sections were a fashionable topic in the late nineteenth and early twentieth centuries after they were discovered in eastern Australia by Ridley (1856 reported in Fison \& Howitt 1880) and studied in Western Australia by Radcliffe-Brown (1913). The first cohort of enthusiasts stoked the fires of various evolutionist theories of the time; however, Radcliffe-Brown chose to explain the system in terms of structural functionalism.

For a time, sections almost disappeared from the world stage in anthropology; however, in the last decades, the topic has re-emerged from the shadows, largely due to the work of Nicholas Allen. He was an early leader in what appears now to be a significant trend in contemporary anthropology: attempting to reconstruct early human society and family. Echoes of the nineteenth-century social evolutionists can be heard quite clearly in the content of their theories and methods, which are often speculative.

In a series of articles and chapters, Allen (1986) proposed that the 'primal' form of human society was 'tetradic'-a system of four sociocentric divisions consisting of a cross-cutting of exogamous lineal and endogamous generational moieties. Fison and Howitt (1880, endorsed by Morgan) also saw the section system as the primordial human family system. Allen sketched the changes ('rupturing of equations') that produced the later kinship systems from this foundation. His offerings were surprisingly well received by social anthropologists considering how they had almost all eschewed 'conjectural history' for nearly a century following the dictates of Radcliffe-Brown.

The 'tetradic society' has a remarkable resemblance to the section systems of Australia, and Godelier sees Allen's inspiration in this. However, Allen (2008, pp. 108-9) has recently denied this and claimed that the tetradic society concept has nothing to do with Australian sections:

Godelier (2004) ... thinks that the congruence of egocentric and sociocentric in tetradic systems is unrealistic. This is partly because of certain historical claims by Australianists.

The 'historical claims by Australianists' would appear to be an oblique reference to my own work and that of Dousset. Allen (2008, p. 109) added: 
Although tetradic theory uses some Australianist analytical vocabulary, Australian data are not essential to it. If all Aboriginals had been wiped out by epidemics or genocide before the advent of ethnographers, one or other tetradic structure would still be the simplest way to organise a society where everyone is related to everyone else. It is a matter of logic.

The issue here is evidence-not 'logic' alone. If the Australian section system 'happens to be' the same as the primal society based on Allen's thought experiment, then what is the relationship between the two? The most obvious hypothesis would be that the Australian section system is in some way a remnant 'survival' of this supposed proto-human 'tetradic' system.

However, there is evidence to support the idea that Australian sections are not 60,000 years old as Allen claimed the tetradic system to be, but less than 6,000 years old, and probably more likely 3,000 years old, diffusing through that period up to the twentieth century. The Australian (and Panoan) section systems were a product of a revolution brought about by interaction of moieties of the same kind in neighbouring groups that were in the process of some kind of merger instituting a new system of marriage and filiation. They were not-in Australia, let alone the worldthe primordial system.

\section{Conclusion}

The origin of sections should not be approached by placing this origin at the dawn of human society and reproducing the speculative histories of the old social evolutionists or their modern counterparts. We should put aside the aversion social anthropology has had to studying social dynamics and prehistory and harness the tools we need to generate hypotheses that can be tested with data.

This chapter began with the example of the research into the origin of subsections - the successor in the sequence of sociocentric categories to sections. This was successful in producing a concrete hypothesis that has largely been accepted, but which has also generated alternative interpretations with continued productive debate.

Sections are a more difficult proposition. They are older, more diverse and complex, and not all systems could be analysed in this one chapter. The two main elements addressed were: 
a. a group of section systems found in the north-east of Queensland

b. a widespread system with little internal variation in interior Queensland—here called the Queensland General section system.

A common element in (a) was the background of patrimoieties, whose names related to names of totemic animals - species of eagles or bees. It was demonstrated that the section systems that arose in this region were composed of what had been patrimoieties of this type-two each from two neighbouring groups that had undergone a kind of amalgamation, adding group country exogamy to moiety exogamy, and a rule of filiation to a parent from the other country.

In the case of (b), detailed linguistic analysis was necessary to establish that the origin of sections was not in the same area as (a) to the north of the QG section system, but in the south-west of the QG section systemthat is, at the extreme south of its distribution. One of the oddities that emerged is that this section system did not spread along with the language subgroup with which it is mainly associated, north to south; but rather in the opposite direction, south to north.

This reinforces an important point: institutional origins and spreads that may look at first sight to be closely and functionally related may be relatively independent, and have their own histories and periods of growth and spread. This necessitates detailed and careful study of these histories. The role of historical linguistics - both of inheritance and diffusion-has been a key focus in this chapter; however, many other disciplines can and should be brought into this kind of enquiry in the long term.

For instance, questions can be raised about why sections emerged and spread as they did, as well as why languages also spread, and the relationship between the two processes. Language spread can occur when a group enters an area where the previous population has dwindled due to scarcity of resources; however, the situation has changed enough to attract the new group in. In Australian prehistory, this kind of sequence can be dominated by factors of climate, or a group battling with scarcity moving in on a group better provided with resources. Climate change can be the background for either of these scenarios.

If we direct our attention to the Maric languages of interior Queensland, it can be seen that they are very similar to each other, suggesting an age from first dispersal of not much more than 1,000 years. It may not be a coincidence that in eastern and Central Australia, there was a wet spell 
around 700 to $1000-1150 \mathrm{AD}$, followed by a transition and a particularly dry spell around 1200-1500 AD (Vance et al. 2013; Williams et al. 2010). Williams et al. (2010) claimed that the Aboriginal population increased in this period. A hypothesis could be that Proto-Maric spread from a north-east homeland beginning around 700-800 AD to take advantage of burgeoning resources in the inland in several stages over the next few hundred years - perhaps as deterioration of climatic conditions drove them further on.

According to the hypothesis regarding the origin of the QG section system, it was only created when Maric speakers reached the southern area, which we might estimate as being around 1200-1300 AD. After that, the QG section system diffused back through the Maric area, and this would have been a rapid diffusion because it would certainly have been in place throughout the area well before the arrival of white invaders in the nineteenth century.

Several aspects of this modelling could be incorrect, causing the chronology to be off to some degree- but it is not completely unreasonable. If it is correct, or slightly inaccurate, it shows just how recent the development and spread of at least some of the section systems in Australia are. Certainly, some of the other section systems in Queensland would be older, especially those in north Queensland - only some of which we have examined here. This is a matter for further research; however, my guess is that the oldest would only be a few thousand years old.

The other questions to tackle here are not only why the QG section systems spread back so rapidly across the Maric languages, but also why it followed the boundaries of Maric so well (not perfectly, but still a close fit) when it did spread back. One might think that in its diffusion from the south, the QG section systems could well occupy an entirely different set of areas, both inside and outside Maric. Was it that there existed an internal coherence and dense social network among the Maric languages/ dialects, which at the time would have been mutually intelligible, having just separated from each other a few hundred years previously at most? After the new system was created, it spread rapidly and effectively in this environment; what's more, it reinforced the long-distance kin-like ties that sections provide. 


\section{References}

Allen, N 1986, 'Tetradic Theory: an approach to kinship', JRAI, 17, pp. 87-109. [Reprinted in R Parkin \& L Stone (eds) 2004, Kinship and family: an anthropological reader, Oxford: Blackwell, pp. 221-36.]

Allen, N 2008, 'Tetradic theory and the origin of human kinship systems', in NJ Allen, H Callan, R Dunbar \& W James (eds), Early human kinship: from sex to social reproduction, Oxford: Blackwell, pp. 96-112. doi.org/10.1002/9781444302714.ch5.

Alpher, B 2004, 'Pama-Nyungan: phonological reconstruction and status as a phylogenetic group', in C Bowern \& $\mathrm{H}$ Koch (eds), Australian languages: classification and the comparative method, Amsterdam: John Benjamins, pp. 93-126, Appendix 'Pama-Nyungan Etyma' pp. 387-570. doi.org/10.1075/cilt.249.09alp.

Barnard, A 1978, 'Universal systems of kin categorization', African Studies, 37, pp. 69-81. doi.org/10.1080/00020187808707509.

Barrett, B 2005, Historical reconstruction of the Maric languages of ventral Queensland, Masters thesis, The Australian National University.

Beale, A 1975, The Maric languages, BA honours thesis, The Australian National University.

Breen, GJ 1972, Unpublished fieldnotes Bidyara and Gungabula, 2011, AIATSIS MS159.

Breen, GJ 1973, Bidyara and Gungabula grammar and vocabulary, Monash University, Linguistic Communications 8.

Crowley, T 1981, 'The Mpakwithi dialect of Anguthimri', in RMW Dixon \& BJ Blake (eds), Handbook of Australian languages 2, Amsterdam: John Benjamins B.V., pp. 146-94. doi.org/10.1075/z.hal2.07cro.

Davidson, DS 1928, The chronological aspects of certain Australian social institutions as inferred from geographical distribution, Philadelphia: University of Pennsylvania.

Dixon, RMW 1972, The Dyirbal language of North Queensland, Cambridge: Cambridge University Press. doi.org/10.1017/CBO 9781139084987. 
Dixon, RMW 1981, 'Wargamay', in RMW Dixon \& B Blake (eds), Handbook of Australian languages 2, Amsterdam: John Benjamins, pp. 1-144. doi.org/10.1075/z.hal2.06dix.

Dixon, RMW 1983, 'Nyawaygi', in RMW Dixon \& B Blake (eds), Handbook of Australian languages 3, Amsterdam: John Benjamins, pp. 430-525.

Dixon, RMW 1991, 'Mbabaram', in RMW Dixon \& B Blake (eds), Handbook of Australian languages 4, Amsterdam: John Benjamins.

Dixon, RMW 2002, Australian languages: their nature and development, Cambridge: Cambridge University Press. doi.org/10.1017/CBO 9780511486869 .

Dollin, A, Dollin, L \& Sakagami, S 1997, 'Australian stingless bees of the genus Trigona', Invertebrate Taxonomy, 11, pp. 861-96. doi.org/ 10.1071/IT96020.

Fison, L \& Howitt, AW 1880, Kamilaroi and Kurnai: group-marriage and relationship, and marriage by elopement: drawn chiefly from the usage of the Australian Aborigines: also the Kurnai tribe, their customs in peace and war, Melbourne: G. Robertson.

Fitzgerald, S 1997, 'A preliminary analysis of the laminal lateral in PamaNyungan languages', in D Tryon \& M Walsh (eds) Boundary rider: essays in honour of Geoffrey O'Grady, Canberra: Pacific Linguistics C-136, pp. 155-74.

Fleck, D 2013, Panoan languages and linguistics, Washington DC: American Museum of Natural History Anthropological Papers 99.

Gardner, H \& McConvell, P 2015, Southern anthropology: a history of Fison and Howitt's Kamilaroi and Kurnai, London: Palgrave and Macmillan. doi.org/10.1057/9781137463814.

Godelier, M 2004, Métamorphoses de la parenté. London: Verso (Champs, trans. 'The Metamorphoses of Kinship').

Halcroft, M, Spooner-Hart, R \& Dollin, A 2013, 'Australian stingless bees', in P Vis, S Pedro \& D Rouben (eds), Pot honey: a legacy of stingless bees, New York: Springer, pp. 35-72. doi.org/10.1007/9781-4614-4960-7_3. 
Harvey, M 1986, Ngoni Waray Amungal-yang: the Waray language from Adelaide River, MA thesis, The Australian National University.

Haviland, J 1979, 'Guugu Yimdhirr', in RMW Dixon \& BJ Blake (eds) Handbook of Australian languages 1, Canberra: Australian National University Press, pp. 27-181.

Herschberger, HD \& Herschberger, R 1986, Kuku-Yalanji dictionary, Darwin: SIL-AAB Work Papers B 7.

Hockings, HJ 1884, 'Notes on two Australian species of Trigona', Transactions of the Royal Entomological Society of London, 32(1), pp. 149-57.

Holmer, N 1983, Linguistic survey of south-eastern Queensland, Canberra: Pacific Linguistics D-54.

Hornborg, A 1993, 'Panoan marriage sections: a comparative perspective', Ethnology, 32(1). doi.org/10.2307/3773548.

Hornborg, A \& Eriksen, L 2011, 'An attempt to understand Panoan ethnogenesis in relation to long-term patterns and transformations of regional interaction in western Amazonia', in A Hornborg \& J Hill (eds), Ethnicity in ancient Amazonia: reconstructing past identities from archaeology, linguistics, and ethnohistory, University Press of Colorado, pp. 129-54.

Howitt, AW 1904, The native tribes of south-east Australia, London: Macmillan \& Co.

Jefferies, T 2010, Notes on Maric languages, Unpublished manuscript.

Kensinger, K 1995, How real people ought to live: the Cashinahua of eastern Peru long grove, Illinois: Waveland Press.

Laffan, K 2003, Reconstruction of the Wakka-Kabic languages of southeast Queensland, BA honours thesis, The Australian National University.

Mathew, J 1910a, 'The origin of the Australian phratries and explanation of some of the phratry names', JRAI, 40, pp. 164-70. doi.org/ $10.2307 / 2843147$. 
Mathew, J 1910b, Two representative tribes of Queensland, with an enquiry concerning the origin of the Australian race, London: T. Fisher Unwin.

Mathews, RH 1898, 'Divisions of Queensland Aborigines', Proceedings of the American Philosophical Society, 37(158), pp. 327-36.

Mathews, RH 1899, 'Divisions of some Aboriginal tribes, Queensland', Journal of the Royal Society of New South Wales, 33, pp. 108-14.

Mathews, RH 1900, 'Group names and initiation ceremonies', Journal of the Royal Society of New South Wales, 33, Appendix divisions of some north Queensland tribes, pp. 250-381.

Mathews, RH 1905, 'Ethnological notes on the Aboriginal tribes of Queensland', Transactions of the Royal Geographical Society of Australasia, Queensland, 20, pp. 49-75.

McConnel, U 1939, 'Social organization of the tribes of Cape York Peninsula, North Queensland', Oceania, 10(1), pp. 54-72. doi.org/ 10.1002/j.1834-4461.1939.tb00256.x.

McConvell, P 1985, 'The origin of subsections in northern Australia', Oceania, 56, pp. 1-33. doi.org/10.1002/j.1834-4461.1985.tb02105.x.

McConvell, P 1997, 'Long-lost relations: Pama-Nyungan and northern kinship', in P McConvell \& N Evans (eds), Archaeology and linguistics: Aboriginal Australia in globalperpsective, Melbourne: Oxford University Press, pp. 207-36.

McConvell, P 2002, Semantic change, Lecture/presentation in Australian comparative linguistics course, The Australian National University.

McConvell, P 2013, 'Proto-Pama-Nyungan kinship and the AustKin project: reconstructing proto-terms for "mother's father" and their transformations', in P McConvell, I Keen \& R Hendery (eds), Kinship systems: change and reconstruction, Salt Lake City: University of Utah Press, pp. 192-216.

McConvell, P \& McConvell, W 2015, 'Mapping pragmatic equivalence of sections and subsections across Australia', Paper presented to the Australian Languages Workshop, Kioloa, March; and CHAGS conference, Vienna, September. 
Oates, L 1988, The Muruwari language, Canberra: Pacific Linguistics C-108.

Pugach, I, Delfin, F, Gunnarsdottir, E, Kayser, M \& Stoneking, M 2013, 'Genome-wide data substantiate Holocene gene flow from India to Australia', PNAS, 110(5), pp. 1803-8. doi.org/10.1073/ pnas. 1211927110.

Radcliffe-Brown, AR 1913, 'Three tribes of Western Australia', JRAI, 43, pp. 143-94.

Radcliffe-Brown, AR 1931, 'The social organization of Australian tribes', Oceania, 1, pp. 1-4 [reprinted as Oceania Monographs 1]. doi.org/ 10.1002/j.1834-4461.1931.tb00015.x.

Ridley, W 1856, 'On the Kamilaroi tribe of Australians and their dialect', Journal of the Ethnological Society of London, 4, 285-93.

Roth, W 1898, 'The Aborigines of the Rockhampton and surrounding coast-districts', in WE Roth (1898-1903), Reports to the commissioner of police and others, on Queensland Aboriginal peoples 1898-1903, FILM 0714 SL Qld.

Roth, W 1904, 'Letter to Howitt', in Howitt collection held at AIATSIS, Canberra. Ms 69, Box 5, Folder 3, Paper 4.

Roth, W 1910, 'North Queensland ethnography', Bulletin no. 18. Social and individual nomenclature. Records of the Australian Museum, pp. 79-106. doi.org/10.3853/j.0067-1975.8.1910.936.

Shapiro, W 1967, 'Semi-moiety organization: some moot points in the literature', Mankind, 6(10), pp. 465-7. doi.org/10.1111/j.18359310.1967.tb01349.x.

Sharp, RL 1939, 'Tribes and totemism in north-east Australia', Oceania, 9(3-4), pp. 254-76, 439-61.

Sim, I 1998, Yuwaalayaay, the language of the Narran River, Walgett, NSW: Walgett High School.

Spencer, B 1914, Native tribes of the Northern Territory of Australia, London: Macmillan \& Co. 
Sutton, P 1973, Gugu-Badhun and its neighbours: a linguistic salvage study, MA thesis, Macquarie University, Sydney.

Terrill, A 1993, Biri: a salvage study of a Queensland language, BA honours thesis, The Australian National University.

Terrill, A 1998, Biri, München: Lincom Europa.

Terrill, A 2002, Dharumbal: the language of Rockhampton, Australia, Canberrra: Pacific Linguistics.

Testart, A 1978, Des classifications dualistes en Australie: essai sur l'évolution de l'organisation sociale, Paris et Lille: Maison des Sciences de l'Homme \& Lille III. doi.org/10.4000/books.editionsmsh.5757.

Thomson, D 1934, 'Notes on a Hero Cult from the Gulf of Carpentaria, North Queensland', JRAIGB\&I, 64, pp. 217-35. doi.org/10.2307/2843808.

Tsunoda, T 2003, A provisional Warrungu dictionary, University of Tokyo, Department of Asian and Pacific Linguistics.

Vance, TR, van Ommen, TD, Curran, MAJ, Plummer, CT \& Moy, AD 2013, 'A millennial proxy record of ENSO and eastern Australian rainfall from the law dome ice core, east Antarctica', Journal of Climate, 26, pp. 710-25. doi.org/10.1175/JCLI-D-12-00003.1.

von Brandenstein, CG 1982, Names and substance in the Australian subsection system, Chicago: University of Chicago Press.

Wafer, J \& Lissarrague, A 2008, A handbook of Aboriginal languages of New South Wales and the Australian Capital Territory, Nambucca Heads, NSW: Muurbay Aboriginal Language \& Culture Cooperative.

Williams, A, Ulm, S, Goodwin, ID \& Smith, M 2010, 'Hunter-gatherer response to late Holocene climatic variability in northern and central Australia', Journal of Quaternary Science, 25(6), pp. 831-8. doi.org/ $10.1002 /$ jqs. 1416 . 
This text is taken from Skin, Kin and Clan: The dynamics of social categories in Indigenous Australia, edited by Patrick McConvell, Piers Kelly and Sébastien Lacrampe, published 2018 by ANU Press, The Australian National University, Canberra, Australia.

doi.org/10.22459/SKC.04.2018.08 